\title{
Öğretmen Adaylarının Problem Kurma Becerilerinin Orantısal Akıl Yürütme Gerektiren Durumlar Bağlamında İncelenmesi ${ }^{1}$
}

\section{İbrahim Bayazit $^{2}$ ve Servet Merve Kırnap Dönmez ${ }^{3}$}

Makale geçmişi

Makale geliş tarihi: 22 Kasım 2016

Yayına kabul tarihi: 23 Şubat 2017

Çevrimiçi yayın tarihi: 3 Nisan 2017

\begin{abstract}
Öz: $\mathrm{Bu}$ çalışmada ortaokul matematik öğretmeni adaylarının problem kurma yeterlikleri incelenmektedir. Konunun, doğal ortamında ve katılımcıların perspektifinden incelenmesi için araştırmada örnek olay metodu kullanılmıştır. Araştırmaya 162 öğretmen adayı katılmıştır. Veriler 10 adet açık uçlu soru içeren yazılı sınav ve sonrasında 8 katılımcıyla yürütülen yarı-yapılandırılmış görüşmelerden elde edilmiştir. Toplanan veriler içerik ve söylem analizi teknikleri kullanılarak analiz edilmiştir. Sonuçlar, katılımcıların yeniden düzenleme sorularından hareketle problemler oluşturmada başarılı olduklarını; ancak bunu yaparken büyük oranda bağlam ve değer değiştirme tekniklerini kullandıklarını göstermektedir. Yarı-yapılandırılmış ve serbest problem kurma durumlarında başarının düştüğü görülmüştür. Oluşturulan problemlerin muhakeme gerektiren nitel karakterli sorular olmaktan ziyade nicel veriler içeren, özgünlük ve yaratıcılıktan uzak, doğru ve ters orantı algoritmalarının direkt uygulanmasıyla çözülebilecek türden rutin karakterli sorular olduğu görülmüştür. Bulgular, öğretmen adaylarının problem kurma konusundaki yetersizliklerinin pedagojik temelli olabileceğine işaret etmektedir. Bu nedenle lisans eğitimi kapsamında problem kurma etkinliklerine yer verilmesinin sorunun çözümüne katkı sağlayacağı söylenebilir.
\end{abstract}

Anahtar Kelimeler: Öğretmen adayları, problem kurma, orantısal akıl yürütme, yeniden düzenleme, yar1yapılandırılmış ve serbest problem kurma durumları

DOI: $10.16949 /$ turkbilmat.303759

\begin{abstract}
This study investigates prospective elementary school teachers' proficiencies at problem posing. The research employed qualitative case study method in order to examine the case in its natural setting and from the participants' perspectives. The research was carried out with 162 prospective elementary mathematics teachers. A written exam, which included 10 open-ended tasks, was administered to the participants; and then semistructured interview was conducted with 8 participants. Data were analyzed through content and discourse analysis methods. The results indicated that most of the participants were not proficient enough at posing conceptually rich and cognitively challenging problems. They displayed relatively better success at generating problems through re-formulation tasks; yet, they did this by changing story of the original tasks or the numerical values in it. Their success declined gradually when they were generating problems from semi-structured and free problem posing situations. The problems that they constructed excluded mathematical reasoning and creativity; these tasks could be resolved by the application of rules, procedures and factual knowledge. The participants' lack of proficiency at problem posing seems to be resulting from their educational backgrounds. Thus, it is suggested that engaging prospective teachers in problem posing activities, especially in semi-structured and free situations, during their undergraduate education will contribute to the solution of this problem.
\end{abstract}

Keywords: Prospective teachers, problem posing, proportional reasoning, reformulation, semi-structured and free problem posing situations

See Extended Abstract

\footnotetext{
${ }^{1} \mathrm{Bu}$ çalışma, İlköğretim Matematik Öğretmen Adaylarının Problem Kurma Becerilerinin İncelenmesi (Kırnap-Dönmez, 2014) başlıklı Yüksek Lisans Tez Çalışmasından üretilmiş; Erciyes Üniversitesi BAP birimi tarafından SBY-11-3833 kodlu Yüksek Lisans Tez Projesi olarak desteklenmiş ve makalenin özeti TÜRKBİLMAT-II Sempozyumunda sözlü bildiri olarak sunulmuştur.

${ }^{2}$ Doç. Dr., Erciyes Üniversitesi, Eğitim Fakültesi, Matematik Eğitimi ABD, Türkiye, ibayazit@erciyes.edu.tr

${ }^{3}$ Arş. Gör., Erciyes Üniversitesi, Eğitim Fakültesi, Matematik Eğitimi ABD, Türkiye, mervekirnap@erciyes.edu.tr
} 


\section{Giriş}

Problem kurma bir durum veya deneyimden hareketle yeni bir soru üretme veya verilen bir problem üzerinde değişiklikler yaparak yeni bir soru oluşturma olarak tanımlanmaktadır (Duncer, 1945'ten akt., Abu-Elwan, 1999; Silver, 1994). Literatürde iki tür problem kurma durumundan bahsedilmektedir. Birinci durumda ortamda daha önce oluşturulmuş bir problem mevcuttur ve kişiden eldeki problemden esinlenerek yeni bir problem oluşturması istenir. İkinci durumda, ortamda bir problem yoktur; ancak bizi problem kurmaya götürecek resim, hikâye, cebirsel yapılar, gerçek yaşam durumu ve grafik türünden çeşitli uyaranlar vardır. Zorluk derecesi ve bireylere sunduğu düşünce özgürlüğü itibariyle bu iki durum arasında niteliksel bir fark olduğu aşikârdır; ancak hangi durum üzerinde çalıştırılırsa çalıştırılsın problem kurma etkinliklerinin öğrencilerin zihinsel gelişimine büyük katkı yaptığı bilinmektedir. Matematik Öğretmenleri Ulusal Konseyi (National Council of Teachers of Mathematics [NCTM], 1989) problem kurmay1 matematik yapmanın en etkili yolu olarak ifade etmektedir. Problem kurma uygulamalı ve soyut matematiğin önemli bir unsuru ve gerçek yaşam durumlarının matematiksel olarak modellenmesi sürecinin ayrılmaz bir parçasıdır (Christou, Mousoulides, Pittalis, PittaPantazi \& Sriraman, 2005).

Matematik ders programlarında ve sınıf içi öğretimlerde problem kurma etkinliklerine yer verilmesi 1srarla önerilmektedir (Brown \& Walter, 1993; Kilpatrick, 1987; Moses, Bjork \& Goldenberg, 1990; NCTM, 1991; Silver, 1994). Ulusal kaynaklarda da konunun önemi vurgulanmakta ve yeni matematik öğretim programında öğrencilerin problem kurma etkinlikleri üzerinde çalıştırılması önerilmektedir (Milli Eğitim Bakanlığ [MEB], 2013). Bu önerilere kaynaklık eden temel felsefe, problem kurma etkinliklerinin kavramların, bağıntıların ve işlemsel süreçlerin ilişkilendirilmesine olanak tanıdığı, matematik ile diğer disiplinler ve gerçek yaşam arasında ilişkilerin kurulmasına imkân verdiği düşüncesidir. Problem kurma etkinliklerinin öğrencilerin yaratıcı ve esnek düşünebilme yeteneklerinin yanı sıra problem çözme yeterliklerinin gelişimine katkı sağladığı belirtilmektedir (English, 1997; Silver, 1994). Matematiğin ne olduğu hakkında öğrencilerin daha gerçekçi bir düşünce geliştirmelerinin önünü açtığı, geçmiş bilgilerini pekiştirmelerine ve zenginleştirmelerine olanak tanıdığı bilinmektedir.

Öğrencilerin problem kurma becerilerini inceleyen çalışmaları iki grupta değerlendirmek mümkündür. Bunlardan ilki katılımcıların problem kurma yeterliklerini inceleyen tarama çalışmalarıdır. Sonuçlar her yaş ve öğrenim seviyesinden öğrencilerin büyük çoğunluğunun problem kurma etkinliklerinde yeterince başarılı olamadıklarını göstermektedir (Crespo \& Sinclair, 2008; Çelik, 2010; Dede ve Yaman, 2005; English, 1998; Stickles, 2006). Öğrencilerin yaratıcı ve eleştirel düşünce içeren, konular ve disiplinler arası bilgi transferi gerektiren sorular oluşturmakta yetersiz kaldıkları; daha ziyade çözüm yöntemi ve stratejisi açık, ezber bilgilerin ve kuralların uygulanmasıyla çözülebilen rutin sorular oluşturdukları rapor edilmektedir (Crespo \& Sinclair, 2008; Korkmaz ve Gür, 2006).

Leung ve Silver (1997) sınıf öğretmeni adaylarının nicel veriler içeren durumlardan hareketle problem oluşturmada başarılı olduklarını, ancak aynı başarıyı nitel karakterli 
problem kurma durumlarında gösteremediklerini belirtmektedir. Stickles (2006) öğretmen adaylarının yarı-yapılandırılmış ve serbest problem kurma durumlarından hareketle yeni sorular oluşturmada zorlandıklarını rapor etmektedir. Stickles bu yetersizliğin katılımciların problem kurma konusundaki deneyimsizliklerinden, alandaki bilgi ve teorik alt yapı eksikliklerinden kaynaklandığını belirtmektedir. Crespo ve Sinclair (2008) öğretmen adaylarının problem kurma yeterliklerini düzlem geometrisi çerçevesinde incelemiştir. Sonuçlar, üretilen 133 sorudan 124 tanesinin tanımları ve bunların özelliklerini konu edinen, formül kullanımıyla alakalı bilgiler gerektiren rutin problemler olduğunu göstermiştir. Katılımcılardan sadece 6 tanesinin analiz ve sentez gerektiren, soyutlama-genelleme yapmayı içeren, farklı yöntem ve stratejilerle çözülebilen problemler oluşturabildikleri görülmüştür. Ülkemizde yapılan çalışmalar da benzer sonuçlar ortaya koymuştur. Örneğin, Korkmaz ve Gür'ün (2006) çalışması ortaöğretim matematik öğretmenliğgi ve sinıf öğretmenliği bölümü öğrencilerinin matematik ders kitaplarındaki dört işlem problemlerine benzer sorular ürettiklerini göstermektedir. Söz konusu çalışmada matematik öğretmeni adaylarının kendilerinden beklenen matematiksel düşünme ve akıl yürütme becerilerini sergileyemedikleri belirtilmektedir.

Problem kurma konusunda yapılan ikinci tür çalışmalar ise deneysel metotların kullanıldığı araştırmaları içermektedir. Sonuçlar problem kurma konusunda verilen eğitimin katılımcıların bu alandaki yeterliklerini artırdığına ilişkin kanıtlar sunmaktadır. Abu-Elwan (2002) matematik öğretmeni adaylarıyla yaptığ 1 çalışmada deney ve kontrol grubu öğrencilerine problem çözme etkinlikleri yaptırmıştır. İlave olarak deney grubundakilere problem kurma stratejileri konusunda eğitim vermiş ve ilgili etkinlikler üzerinde çalıştırmıştır. Sonuçlar, deney grubu öğrencilerinin problem kurma ve problem çözme konularında akranlarından daha başarılı olduklarını göstermektedir. Lavy ve Shriki (2007) problem kurma eğitimi alan öğretmen adaylarının kavramların tanımlarını ve özelliklerini açıklama yeteneklerinin geliştiğini, kavramlar arasında bağlantılar kurabildiklerini belirtmektedir. Problem kurma konusunda verilen eğitimin alan bilgisinin yanı sıra pedagojik alan bilgisinin gelişimini de desteklediği bilinmektedir (Silver, 1994). $\mathrm{Bu}$ alandaki temel kazanımlar ise matematik dilini etkili kullanabilme ve alan bilgisini öğrencilerin bilişsel düzeylerine göre uyarlayıp sunabilme becerilerini içermektedir.

Özetle, problem kurma etkinliklerinin eleştirel ve yaratıcı düşünceyi geliştirdiği, öğrencilerin analiz-sentez ve soyutlama-genelleme becerilerini artırdığı ve öğrencilerin kavramsal bilgi edinmelerinin önünü açtığı söylenebilir. Ayrıca, motivasyon, özgüven, matematiğe karşı tutum ve davranış türünden duyuşsal alanlarda da olumlu etkilerinin olduğu belirtilebilir. Ancak, yukarıda sunulan araştırma sonuçları öğrencilerin problem kurma sürecinde ciddi sıkıntılar yaşadıklarını göstermektedir. Türkiye'de öğretmen adaylarının problem kurma becerilerini inceleyen az sayıda çalışma bulunmaktadır. $\mathrm{Bu}$ çalışmalarda ağırlıklı olarak nicel yöntemler kullanıldığı için problem kurma sürecinde sergilenen yaklaşımlar, kullanılan stratejiler ve üretilen soruların niteliğine ilişkin detaylı bilgi ve bulgular ortaya konulamamıştır. Bu nedenle, eldeki çalışmada İlköğretim Matematik Öğretmeni adaylarının problem kurma becerilerinin nitel yöntemlerle 
incelenmesi hedeflenmiştir. Çalışma kapsamında 'İlköğretim matematik öğretmen adaylarının problem kurma becerileri nasildır?' sorusuna yanıt aranmaktadır. Araştırmanın öğretmen adaylarının problem oluşturma sürecinde sergiledikleri yaklaşımlar, kullandıkları teknikler, bunların pedagojik ve bilişsel temellerine ilişkin aydınlatıcı bilgiler ortaya koyduğunu söyleyebiliriz. Araştırma yönteminin izahına geçmeden önce eldeki çalışmanın matematiksel bağlamını oluşturan orantısal akıl yürütme kavramı kısaca açıklanacaktır.

\subsection{Orantısal Akıl Yürütme}

Kavramlar arası ilişkilerin kurulmasında orantısal akıl yürütmenin önemli bir işlevi vardır; bu nedenle matematik ders programlarının özünü teşkil eden temel düşüncelerden biri olarak kabul edilmektedir (Lesh, Post \& Behr, 1988). Hız-zaman, havuz ve karışım problemlerinin çözümünün yanı sıra geometri, cebir, olasılık ve trigonometri konularının anlaşılması için orantısal akıl yürütmenin gerekli olduğu bilinmektedir. Orantısal akıl yürütme güncel yaşamda da yaygın olarak kullanılmaktadır. Örneğin, finans sektöründe kar-zarar ve faiz hesapları yaparken, gerçek yaşamda pasta tariflerinde, alışveriş yaparken hangi ürünü almanın daha avantajlı olduğunu anlamaya çalışırken farkında olmadan orantısal akıl yürütme becerimizi kullanırız.

İki çokluğun bölme yoluyla kıyaslanmasına oran, aynı türden iki oranın eşitliğine ise orantı denir. Orantısal akıl yürütme, oran ve orantı kavramlarına kıyasla daha üst düzey bir düşünme becerisini ifade eder. En sade şekliyle orantısal akıl yürütme iki veya daha fazla oranın eşitliğini içeren ortamlardaki nicel veya nitel çokluklar arasında var olan çarpımsal ilişkinin anlaşılıp yorumlanması biçiminde tanımlanabilir (Behr, Harel, Post \& Lesh, 1992; Cramer, Post \& Currier, 1993; Lamon, 1995). Orantısal akıl yürütmenin temel özelliği çokluklar arasındaki çarpımsal ilişkinin anlaşılmasıdır. Örneğin, 'bir sürahiyi doldurmak için 10 bardak suya ihtiyaç varsa aynı büyüklükte üç sürahiyi doldurmak için kaç bardak su gerekir' sorusunu ele alalım. Bu soruda, sürahi sayısı 3 katına çıktığı için ihtiyaç duyulan su miktarının da üç katına çıkacağı hususunun anlaşılması, çözüm sürecinin çokluklar arasında var olan bu çarpımsal ilişki gözetilerek yürütülmesi orantısal akıl yürütme becerisinin en açık örneğidir.

Orantısal akıl yürütme gerektiren durumlarda, değerler arasında mutlak bir değişim olduğu ve içerisinde toplamsal ilişkiyi barındırdığı algısı yerine bileşenler (değişkenler) arasında bağıl (göreceli) bir değişim olduğu ve aralarında çarpımsal ilişki bulunduğu düşüncesiyle hareket edilmesi önem arz etmektedir. Mutlak ve bağıl değişim şu örnek üzerinden daha iyi anlaşılabilir: " $A$ ve $B$ ağaçlarının şu andaki boyları 1,5 metre ve 2 metre olsun. Bir yıl sonra ölçüm yapıldı̆̆ında A ă̆acının boyunun 2 metre, $B$ ağacının boyunun ise 2.5 metre olduğu görülüyor. A ve B ağaçlarının şu andaki boylart ile bir yıl sonraki boylarını karşılaştırarak büyümeleri hakkındaki düşüncelerinizi ifade ediniz" (Lamon, 1995, s. 227). Sorunun çözümünde iki farklı yaklaşım sergilenebilir. İlkinde, problem çözücü değişkenler arasındaki toplamsal ilişkiyi esas alarak her iki ağacın mutlak büyüme miktarlarını kıyaslayabilir (her ikisi de $0,5 \mathrm{~m}$ uzamışır); bu nedenle de ağaçlarının aynı oranda büyüdüğünü iddia edebilir ki bu yanlış bir çıkarımdır. Doğru 
sonuç her bir ağacın büyüme oranının kendi bağlamında değerlendirilmesi (birinci ağaç: $\frac{2}{1,5}$, ikinci ağaç: $\frac{2,5}{2}$ ) ve sonuçların mukayese edilmesiyle elde edilebilir.

Orantısal akıl yürütme çokluklar arasındaki çarpımsal ilişkiyi sayılar, tablolar, grafikler ve cebirsel dille ifade edebilmeyi içerir (NCTM, 2000). Nicel değerler arasında kıyaslamalar yapabilmenin yanı sıra nitel yöntemlerle tahmin ve çıkarım yapabilmeyi içeren bir akıl yürütme becerisidir (Lesh, Post \& Behr, 1988). Esasında, nitel yapılar arasındaki çarpımsal ilişkilerin anlaşılması ve yorumlanması orantısal akıl yürütme becerisinin gelişiminin en önemli göstergesidir denilebilir. Örneğin, 'Gökçe dün yaptığına kıyasla bugün daha az limon ve daha çok su kullanarak limonata yapmıştır. Dünkü ve bugünkü içtiği limonataların tadını değerlendiriniz' sorusunun çözümü azlık ve çokluk kavramlarıyla ifade edilen nitel çokluklar arasındaki ilişkiyi doğru anlamakla mümkündür.

Özetle, birçok matematik konusu kapsamında ve gerçek yaşamda aktif olarak kullanılıyor olması orantısal akıl yürütmeyi önemli kılmaktadır. Bu nedenle öğretmen adaylarının problem kurma becerileri söz konusu düşünce özelinde araştırılmıştır. Eldeki çalışmayı önemli kılan en temel husus araştırmada ağırlıklı olarak nitel yöntemlerin kullanılmış olmasıdır. Bu özelliği nedeniyle öğretmen adaylarının problem kurma sürecinde işe koştukları düşüncelerin niteliği, kullandıkları strateji ve teknikler ile bunların pedagojik ve bilişsel temellerine ilişkin önemli bulgulara ulaşılmıştır. Araştırmanın yöntemi ve bu süreçte kullanılan veri toplama ve analiz teknikleri bir sonraki bölümde açıklanmıştır.

\section{Yöntem}

Öğretmen adaylarının problem kurma becerilerinin ve bu süreçte sergiledikleri düşünce süreçlerinin incelenmesi eldeki çalışmanın amacını oluşturmaktadır. $\mathrm{Bu}$ ise kurdukları problemlerin niteliği, verilen problem kurma durumlarıyla uyumluluğu, eksik bilgi içerip içermediği, hangi tür orantısal akıl yürütmenin kullanıldığı, problem kurarken bağlam, çözüm yöntemi, çözüm stratejisi ve problem kurma durumundaki nicel-nitel değerlerden hangisinde değişiklikler yapıldığı hususlarının incelenmesini gerektirir. Söz konusu nedenlerden ötürü çalışma konusunun bütüncül bir yaklaşımla, kendi doğal ortamında ve katılımcıların bakış açısıyla incelenmesi; neden, niçin ve nasıl sorularına yanıt teşkil edecek nitel bulgulara ulaşılması için bu araştırmada örnek olay (durum çalışması) metodu kullanılmıştır (Yin, 2003; Yıldırım ve Şimşek, 2008). Çalışma bir devlet üniversitesinde, Eğitim Fakültesi İlköğretim Matematik Öğretmenliği Bölümünde okuyan 162 öğretmen adayının (87'si üçüncü sınıf, 75’i dördüncü sınıf öğrencisi) katılımıyla gerçekleştirilmiştir. Araştırmanın uygulandığı tarih itibariyle katılımcılar Özel Öğretim Yöntemleri I-II ve Öğretim Teknolojileri ve Materyal Tasarımı türünden alan eğitimi derslerinin yanı sıra matematik alan derslerinin büyük bir kısmını almış bulunmaktaydılar; dolayısıyla problem kurma konusunda gerekli bilgi birikimine sahip oldukları varsayılabilir. 


\subsection{Veri Toplama Araçları}

Veriler yazılı sınav ve yarı-yapılandırılmış mülakat teknikleriyle toplanmıştır. Sorulardan iki tanesi literatürden uyarlanarak oluşturulmuş; diğerleri ise araştırmacılar tarafindan geliştirilmiştir. Bir devlet üniversitesinin İlköğretim Matematik Öğretmenliği Bölümünde öğrenim gören 22 öğretmen adayı üzerinde pilot çalışma yapılmıştır. Ayrıca, soruların hedefle uyumluluğu, dil ve içerik açısından uygunluğu konularında uzman görüşlerine başvurulmuştur. Ana çalışma kapsamında ilk olarak, 10 adet açık uçlu sorudan oluşan yazılı sınav tüm katılımcılara eş zamanlı olarak uygulanmıştır. Sınav yaklaşık bir saat sürmüştür. Katılımcıların birbirlerinden etkilenmemeleri için sınav esnasında gerekli önlemler alınmıştır. Yazılı sınavın ilk bölümünde 3 adet yeniden düzenleme sorusuna, ikinci bölümünde 5 adet yarı-yapılandırılmış problem kurma durumuna ve üçüncü bölümünde ise 2 adet serbest problem kurma durumuna yer verilmiştir.

Yeniden düzenleme soruları kapsamında katılımcılara orantısal akıl yürütme gerektiren sorular verilmiş ve bu sorulardan hareketle yeni problemler kurmaları istenmiştir. Bu bölümde nicel ve nitel muhakeme gerektiren problem kurma durumlarının kullanılmasına özen gösterilmiştir. Bu bölümde kullanılan sorulardan bir tanesi şu şekildedir:

Ahmet her gün aynı pistte koşu yapmaktadır. Bugün dün koştuğundan daha fazla sürede daha az tur koşmuştur. Buna göre dünkü ve bugünkü hızlarını karşılaştırınız (Cramer, Post \& Currier 1993 'ten uyarlanmıştır).

Yarı-yapılandırılmış problem kurma durumlarının temel özelliği öğrencilere daha fazla düşünme özgürlüğü tanımasıdır. Bu kısımda, birer adet aritmetiksel ve cebirsel ifade, bir adet dikdörtgen şeklinde karolardan oluşan görsel model ve iki adet gerçek yaşam durumu verilmiş; katılımcılardan bu durumlara ilişkin orantısal akıl yürütmeyle çözülebilecek problemler kurmaları istenmiştir. $\mathrm{Bu}$ kısımda kullanılan sorulardan bir tanesi şu şekildedir:

Aşağıdaki resimden hareketle orantısal akal yürütmeyle çözülebilen bir problem oluşturunuz.

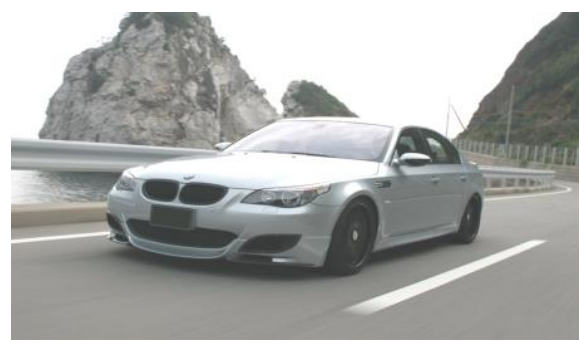

Şekil 1. Yarı-yapılandırılmış problem kurma durumu.

Serbest problem kurma durumları kapsamında ilham kaynağı olabilecek görsel veya yazılı herhangi bir uyarıcı kullanılmamıştır. Katılımcılardan biri gerçek yaşamla alakalı diğeri 
de çözümünün zor olduğunu düşündükleri iki adet problem kurmaları istenmiştir. Bunlardan bir tanesi şu şekildedir:

Orantısal akıl yürütme gerektiren ve çözümünün zor olduğunu düşündüğ̈̈nüz bir problem kurunuz.

Yazılı sınavdan sonra sekiz öğretmen adayıyla yarı-yapılandırılmış görüşmeler gerçekleştirilmiştir. Çalışmada, görüşme yapılan öğretmen adaylarının gerçek isimleri yerine kod adları kullanılmıştır. Katılımcılar yazılı sınavın ön analiz sonuçları dikkate alınarak belirlenmiştir. Ön analizler, katılımeıların ürettikleri soruların niteliği, yeniden düzenleme, yarı-yapılandırılmış ve serbest problem kurma durumlarındaki başarıları, bağlam, yöntem ve strateji değişikliklerinden hangisine yöneldikleri, oluşturulan problemlerin çözümünde kullanılabilecek yöntem ve strateji çeşitliliği gibi kriterler gözetilerek gerçekleştirilmiştir. Neticede, öğretmen adayları, kendi içinde görecelilik arz etmekle birlikte, başarıll, orta düzeyde başarılı ve başarısız olmak üzere üç grupta toplanmıştır. Grup sayılarıyla orantılı olacak şekilde görüşmelerde başarılı gruptan 2, orta düzeyde başarılı gruptan 4 ve başarısız gruptan 2 öğrenciye yer verilmiştir. Görüşmelerde, yazılı sınavda kullanılan sorular öğretmen adaylarına teker teker yöneltilmiş ve her bir durumla alakalı kurabildikleri kadar yeni problemler kurmaları istenmiştir. Konuşmanın akışı gelen yanıtlara göre şekillenmiş; neden, niçin ve nasıl içerikli sorularla katılımcıların düşünce süreçlerine ulaşılmaya çalışılmıştır (Gingsburg, 1981). Her bir öğretmen adayıyla yapılan görüşme 45-90 dakika sürmüş, veriler ise ses kayıt cihazlarına depolanmıştır. Önemli noktalar araştırmacı tarafından görüşme esnasında veya sonrasında yazılı olarak kaydedilmiştir. Düşüncelerini yazılı olarak ifade edebilmeleri için öğretmen adaylarına kâğıt ve kalem verilmiştir.

\subsection{Veri Analizi}

Toplanan verilerin derinlemesine incelenmesi, yazılı ve sözlü yanıtların arkasındaki anlamlara ulaşılması amacıyla analiz sürecinde içerik ve söylem analizi yöntemleri kullanılmıştır (Miles \& Huberman, 1994; Phillips \& Hardy, 2002). Araştırmada kullanılan problem kurma durumları içerik ve kullanım amaçları itibariyle farklılaştığı için verilerin analizinde tek bir kuramsal çerçeve kullanmaktan kaçınılmıştır. Takip edilen temel yöntem ve yaklaşımlar aynı kalmakla birlikte her bir problem kurma durumunun içeriği ve özgün koşuları düşünülerek analizler yapılmıştır. Bu süreçte problem kurma (Grundmeier, 2003; Silver \& Cai, 1996; Stickles, 2006) ve orantısal akıl yürütme (Lesh, Post \& Behr, 1988; Patricia, Post, Behr \& Lesh, 1990) konularıla alakalı literatür bilgilerinden genel manada kuramsal çerçeve olarak yararlanılmıştır.

Yeniden düzenleme soruları kategorisinde üretilen problemler öncelikle çözülebilir olması açısından incelenmiştir. Mantık hatası ve yetersiz bilgi içerdiği için çözülemez bulunan sorular üzerinde analiz işlemlerine devam edilmemiş, cevap verilmeyen sorularla birlikte 'değerlendirmeye alınmayanlar' kategorisi altında toplanmıştır. Çözülebilir olan problemlerin, ilk verilen problem durumlarıyla kıyaslanarak analizlerine devam edilmiştir. 
İlk olarak, problem oluşturma sürecinde kullanılan teknikler, kaynak soru üzerinde yapılan değişiklikler, bu değişikliklerin işlemsel ve kavramsal alanlardan hangisiyle alakalı olduğu gibi hususlarda yapılan tespitler kısa kodlarla ifade edilmiştir. Problem oluşturma sürecinde sergilenen düşüncelerin ve kullanılan tekniklerin doğallığını yansıtacak şekilde kodlar ortamdan üretilmiştir. Sürecin ileriki aşamalarında ise kodlar arasındaki anlamsal ilişkiler incelenmiş, ana tema olarak yakın olanlar birlikte değerlendirilerek genel kategoriler altında toplanmıştır. Kategorilerin oluşturulmasında ise Grundmeier (2003) ve Stickles'in (2006) çalışmalarından faydalanılmıştır. Örneğin, öğretmen adayı soru içindeki sayısal verileri yenileriyle değiştirdiyse veya nitel çoklukları ifade etmek için kullanılan 'daha az', 'daha çok' gibi kavramları değiştirerek yine nitel karakterli yeni sorular oluşturduysa 'değer değiştirme' olarak sınıflandırılmıştır. Nitel karakterli sorularda ortama dişarıdan sayısal değerler eklediyse 'sayısal veri ekleme', sorunun çözüm sürecini (işlem basamaklarını) uzatacak şekilde nitel veya nicel yeni çokluklar ilave ederek kıyaslanacak durumların sayısını artıdıysa 'genişletme' olarak tespit edilmiştir. Problemi daha kolay çözülebilir hale getirmek için kaynak sorunun çözüm sürecini ve işlem basamaklarını kısaltacak şekilde değişiklikler yapmışsa 'basitleştirme', sorunun içeriğini ve işlem basamaklarını aynı tutup sadece hikâyesini değiştirdiyse 'bağlam değisstirme' başlığı altında gruplandırılmıştır. Bu alanların iki veya daha fazlasında değişiklikler yapılarak üretilen sorular ise 'kombinasyon' kategorisinde değerlendirilmiştir. Kategori oluşturma sürecinin anlaşılması için genişletme tekniği kullanılarak üretilen örnek bir problem aşağıda verilmiştir. Bu soru bir önceki kısımda verilmiş olan nitel karakterli koşu sorusundan hareketle üretilmiştir. Kaynak soruda, Ahmet'in ardışık iki günde yaptığı koşu süreleri ve tur sayıları verilmekte ve bunlar arasında kıyaslama yapılması istenmektedir. Aşağıdaki soruda ise problem kurucunun kaynak sorudakilere ilave olarak üçüncü bir gün için koşu süresi ve tur sayısı vererek kıyaslanacak çokluk sayısını artırdığı, dolayısıyla içerik olarak aynı ancak işlem süreci olarak daha uzun yeni bir soru oluşturduğu görülmektedir.



Alıntı 1. Genişletme tekniği kullanılarak oluşturulmuş problem örneği [ÖA-129] ${ }^{4}$

Yapılan analizlerde üretilen problemlerden bir kısmının, ilk verilen problem kurma durumlarına kıyasla, yöntem ve strateji kullanımında değişiklikler içerdiği, orantısal akıl yürütmenin uyarlanarak kullanımını gerektirdiği, niteliksel değişim içerdiği (nicel karakterli soruların nitel karakterli problemlere dönüştürülmesi gibi) ve aklın daha etkili kullanımını zorunlu kıldığı görülmüştür. Bu ve benzeri alanlarda esasa ilişkin niteliksel

${ }^{4}$ [ÖA-129]: Yazılı sınavdaki 129 numaralı öğretmen adayını belirtmektedir. 
değişim içeren sorular uygun biçimde kodlanmış ve analizin son aşamasında ise 'yapısal değişim' kategorisi altında değerlendirilmiştir.

Yart-yapılandırılmış ve serbest problem kurma durumlarıla alakalı oluşturulan problemlerin analizinde yukarıdakine benzer bir yol takip edilmiştir. Mantık hatası ve eksik bilgi içeren problemler ile yanıtsız bırakılmış olan sorular 'değerlendirilmeye alınmayanlar' kategorisinde toplanmıştır. Orantısal akıl yürütmenin dışında farklı matematiksel düşünceler içeren problemler (dört işlem problemi, denklem kurma problemi, vs.) konusuna göre uygun kodlarla tespit edilmiş ve 'farklı konularda oluşturulmuş problemler' başlığı altında sınıflandırılmıştır. Çözülebilir olan ve orantısal akıl yürütme becerisi içeren problemler ise içeriği yansıtacak biçimde (doğru orantı, ters orant1, niceliksel karşılaştırma, niteliksel karşılaştırma, vs.) uygun kodlarla tespit edilmiş ve 'orantısal akll yürütme gerektiren problemler' genel kategorisi altında toplanmıştır.

İlave olarak, serbest problem kurma durumlarıyla alakalı üretilen problemlerin zorluk dereceleri açısından analizinde ise Uluslararası Matematik ve Fen Eğilimleri Araştırması'nın (Trends in International Mathematics and Science Study [TIMSS]) (2011) raporunda yer alan kuramsal çerçeveden yararlanılmıştır. Buna göre üretilen sorular bilgi, uygulama ve muhakeme soruları olmak üzere üç grupta toplanmıştır. Orantı kavramıyla alakalı ezber bilgilerin ve kavram tanımının direkt kullanımıyla çözülebilen problemler bilgi sorusu olarak değerlendirilmiştir. Orantı kavramıyla alakalı içler-dışlar çarpımı algoritması türünden işlemsel bilgilerin işe koşulmasıyla çözülebilen sorular uygulama sorusu kategorisinde sınıflandırılmıştır. Düşünceyi zorlayan, nitel çokluklar arasındaki çarpımsal ilişkiyi konu edinen ve muhakeme temelli yordama ve soyutlama yapmayı gerektiren problemler ise muhakeme sorusu olarak belirlenmiştir. Yazılı sınav kâğıtlarının analizi neticesinde her bir soruya ilişkin üretilen kod/kategoriler numaralandırılarak SPSS programına aktarılmış, böylece yüzde-frekans değerleri hesaplanmıştır. Analizlerin araştırmacılar tarafından birkaç kez ve eş zamanlı olarak yapılması ve üretilen kod/kategorilerin SPSS ortamına aktarılarak nicel verilere dönüştürülmesiyle güvenilir ve geçerli bulgulara ulaşılması hedeflenmiştir. Kod ve kategorilerle alakalı araştırmacılar arasında ortaya çıkan uyuşmazlıklar alanda uzman üçüncü kişilere de danışılarak fikir birliği ile çözüme kavuşturulmuştur.

Öğretmen adaylarıyla yapılan mülakatların analizinde de benzer yöntem ve yaklaşımlar takip edilmiştir. Öncelikle ses kayıt cihazlarına depolanmış olan veriler çözümlenmiş, analiz işlemleri elde edilen yazılı dokümanlar üzerinden yürütülmüştür. $\mathrm{Bu}$ dokümanlar birkaç kez okunmuştur. Oluşturulan problemler yazılı sınav kâğıtlarının analizindekine benzer şekilde kodlanmış, sonrasında ise üretilen kodlar genel kategoriler altında toplanmıştır. Mülakat verilerinin analizinde katılımcıların oluşturdukları problemlerin özelliklerinin yanı sıra problem oluşturmadaki esneklikleri ve problem oluşturma sürecinde dikkat ettikleri hususlara ilişkin yeni tespitler de yapılmıştır. Yazılı sınav ve görüşme verilerinin analizinden elde edilen bulgular bir sonraki bölümde sunulmuştur. 


\section{Bulgular}

$\mathrm{Bu}$ kısımda, öğretmen adaylarının problem kurma konusundaki yeterliklerine ilişkin bulgular paylaşılmaktadır. Yapılan analizler, 'yeniden düzenleme, yarı-yapılandırılmış ve serbest' problem kurma durumlarını kapsayan üç alanın her birinde kullanılan soruların benzer sonuçlar ortaya koyduğunu göstermektedir. Tekrardan kaçınmak için bu kısımda 5 adet problem kurma durumuna ilişkin bulgular paylaşılmış; gerekli hallerde diğer durumlara ilişkin bulgulardan kısaca bahsedilmiştir. Bulguların anlaşılmasını kolaylaştırmak için her bir soruya ilişkin yazılı sınav ve görüşme sonuçları harmanlanarak sunulmuştur. Ayrıca, yazılı sınav ve görüşme bulgularından alıntılara yer verilmiş; yapılan yorumlar alıntıların içeriğiyle sınırlı tutularak aşırı genellemelerden kaçınılmıştır.

Araştırma sonuçları, katılımcıların yarı-yapılandırılmış ve serbest problem kurma durumlarına kıyasla yeniden-düzenleme sorularında daha başarılı olduklarını göstermektedir. Ancak, her üç alanda da öğretmen adaylarının yaratıcılık ve özgünlükten uzak, bilgi sentezlemeleri ve uygulamalar gerektirmeyen, orantısal akıl yürütmeyle alakalı ezber bilgilerin ve kuralların işe koşulmasıyla çözülebilen sorular oluşturdukları görülmektedir. Çözüm yöntemi ve stratejisi gibi esasa ilişkin hususlardan ziyade problemdeki nicel verileri ve soru hikâyesini değiştirerek problemler üretmeye çalışmışlardır. Genişletme ve basitleştirme tekniklerini kullanarak yeni sorular üretenlerin de yine başlangıçta verilen problem kurma durumunun (kaynak sorunun) yapısal özelliklerine, çözüm yöntem ve stratejilerine bağlı kaldıkları, yaptıkları nicel-nitel ekleme ve çıkarmalarla işlemsel süreç üzerinde düzenlemeler yaptıkları görülmüştür. Araştırmadaki 3 adet yeniden-düzenleme sorusundan ilki niceliksel mukayese gerektiren aşağıdaki problemi içermektedir:

I. Durum: A musluğu 3 dakikada 13 litre su akıtmakta, B musluğu ise 4 dakikada 17 litre su akıtmaktadır. Buna göre muslukların su akıtma hızlarını karşılaştırınız.

$\mathrm{Bu}$ sorudan hareketle üretilen problemlerden 11 tanesinin eksik bilgi, 14 tanesinin ise mantık hatası içerdiği görülmüştür (bakınız, Tablo 1). Çözüm için gerekli bilgileri içermeyen sorular 'eksik bilgi', içeriği hakkında matematiksel muhakemenin yapılamadığı sorular ise 'mantık hatası' alt başlığında toplanmış ve boş bırakılanlarla birlikte 'değerlendirmeye alınmayanlar' kategorisinde sınıflandırılmıştır. Örneğin, aşağıdaki sorunun çözümü için havuzun kaç litre su aldığının bilinmesi gerekir; bu bilgi problemde verilmediği için soru eksik bilgi içerenler kategorisinde değerlendirilmiştir.

“A musluğu 3 dakikada 20 litre su akıtmakta B musluğu 4 dakikada 10 litre su boşaltmaktadır. Bu muslukların bulunduğu havuz kaç dakikada dolar?" [ÖA-16]

Üzerinde analiz işlemlerine devam edilen 136 problemin oluşturulmasında ise farklı tekniklerin kullanıldığı görülmüştür. Katılımcılardan 29 tanesi sadece nicel verileri değiştirerek yeni sorular üretirken 27 öğretmen adayı kaynak sorunun bağlamında (hikâyesinde) değişiklik yaparak yeni problemler kurmuştur. Bağlam değişikliği içeren örnek bir yanıt şu şekildedir: 
araba 4 doki bado

5 dowlaston 26 metre

brsibustarinin

Alıntı 2. Bağlam değişikliği tekniği kullanılarak üretilmiş problem örneği [ÖA-40]

Verilen soruda kıyaslanması istenen su akıtma hızlarını bulmak için her bir musluğun akıttığı su miktarını verilen süreye oranlamak gerekir; ancak her iki musluk için de kaynak soruda verilen değerler birbirinin tam katı değildir. Bu da sorunun çözümünü kısmen de olsa zorlaştırmaktadır. Basitleștirme tekniğini kullananlar sadece oranlanacak değerleri birbirinin tam katı olacak şekilde belirleyerek daha kolay çözülebilecek sorular üretmişlerdir. Aşağıdaki örnek yanıtta görüldüğü üzere genişletme tekniğini kullanan 6 öğretmen adayı ise musluk sayısını artırarak verilen problemi yeniden düzenlemiştir.

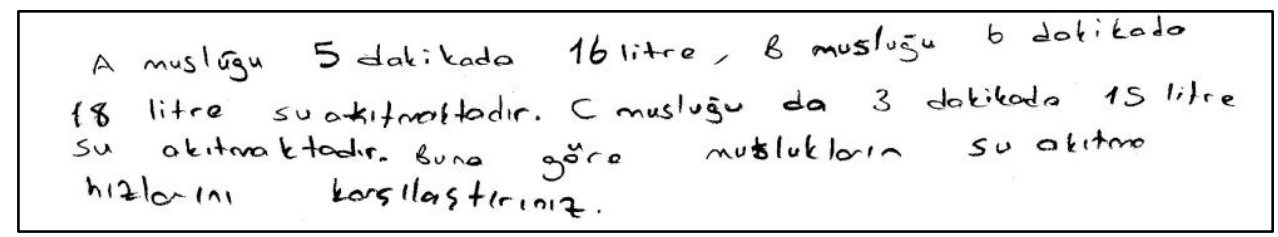

Alıntı 3. Genişletme tekniği kullanılarak üretilmiş problem örneği [ÖA-30]

Tablo 1. I. Problem kurma durumuna ilişkin yazılı sınav analiz sonuçları.

\begin{tabular}{|c|c|c|c|}
\hline \multicolumn{2}{|r|}{ Kullanılan Yöntem } & Frekans & Yüzde \\
\hline \multicolumn{2}{|l|}{ Değer değiștirme } & 29 & 17.9 \\
\hline \multicolumn{2}{|l|}{ Bağlam değiștirme } & 27 & 16.7 \\
\hline \multicolumn{2}{|l|}{ Basitleștirme } & 8 & 4.9 \\
\hline \multicolumn{2}{|l|}{ Genișletme } & 6 & 3.7 \\
\hline \multicolumn{2}{|l|}{ Kombinasyon } & 21 & 12.9 \\
\hline \multicolumn{2}{|l|}{ Yapısal değișim } & 45 & 27.8 \\
\hline \multirow{3}{*}{$\begin{array}{l}\text { Değerlendirmeye } \\
\text { alınmayanlar }\end{array}$} & Yetersiz bilgi & 11 & 6.8 \\
\hline & Mantık hatası & 14 & 8.6 \\
\hline & Yanit yok & 1 & 0.6 \\
\hline \multicolumn{2}{|l|}{ Toplam } & 162 & $\% 100$ \\
\hline
\end{tabular}

Kombinasyon kategorisindeki 21 problemin üretiminde yukarıda bahsedilen tekniklerin iki veya daha fazlası birlikte kullanılmıştır (değer ve bağlam değiştirme gibi). Sonuç olarak, katılımcıların \%56'sı değer ve bağlam değiştirme, basitleştirme ve genişletme türü rutin teknikleri kullanarak problemler oluşturmuşlardır. Bu gruptaki öğretmen adayları kaynak sorunun çözüm yöntem ve stratejisine bağlı kalarak yine niceliksel karşılaştırma problemleri üretmişlerdir. 45 öğretmen adayı ise kaynak problem 
üzerinde yapısal değişikliğe giderek farklı yöntem ve stratejilerle çözülebilen, matematiksel muhakemenin daha etkili kullanımını gerektiren, içerik açıdan zengin ve zihni zorlayan problemler oluşturmuştur. Kaynak sorunun çözümünde iki musluğun su akıtma hızlarını hesaplamak ve bunları birbirleriyle kıyaslamak yeterlidir. Ancak, yapısal değişim problemi olarak değerlendirilen aşağıdaki örnek yanıtta çözüm stratejisinin değiştiği açıkça görülmektedir. Bu problemde muslukların birim zamanda akıttıkları miktarı bulup kaç musluğun ne kadar süreyle su akıttığını hesaplayarak havuzun dolma süresini bulmak gerekmektedir.

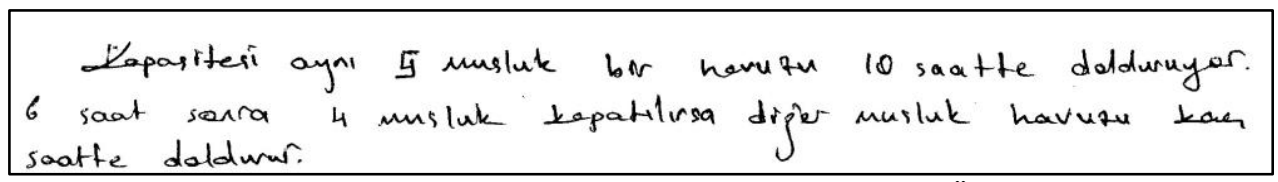

Alıntı 4. Yapısal değişiklik içeren problem örneği [ÖA-2]

Mülakatlar yazılı sınav sonuçlarını destekler bulgular ortaya koymuştur. Mülakatlarda toplam 18 adet problem oluşturulmuştur (Tablo 2; öğretmen adaylarının oluşturduğu her bir soru için ilgili kategoriye $\mathbf{x}$ işareti konulmuştur). Oluşturulan sorulardan 5 tanesi çözüm sürecine ilişkin değişiklik ve yöntemsel farklılık içerirken geri kalanlar değer ve bağlam değiştirme türünden rutine ilişkin uyarlamalar içermektedir.

Tablo 2. I. Problem kurma durumuna ilişkin görüşme bulguları.

\begin{tabular}{|c|c|c|c|c|c|c|c|c|}
\hline Kullanılan Yöntem Katılımcılar & $\underset{\Xi}{\Xi}$ & $\frac{\pi}{\sqrt[n]{\pi}}$ & : & 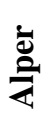 & $\underset{=}{\mathscr{E}}$ & 颉 & $\underset{\mathrm{Z}}{\mathrm{Z}}$ & 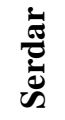 \\
\hline Değer değiștirme & $\mathrm{x}$ & & & & $\mathrm{xx}$ & & & \\
\hline Bağlam değiştirme & & & & & & & $\mathrm{XX}$ & \\
\hline Basitleștirme & & & & $\mathrm{x}$ & & & & \\
\hline Kombinasyon & $\mathrm{x}$ & $\mathrm{x}$ & $\mathrm{x}$ & $\mathrm{x}$ & & & $\mathrm{X}$ & \\
\hline Yapısal değişim & & & & & & $\mathrm{xx}$ & & $\mathrm{xxx}$ \\
\hline Değerlendirmeye alınmayanlar & $\mathrm{x}$ & & & $\mathrm{x}$ & & & & \\
\hline Toplam & 3 & 1 & 1 & 3 & 2 & 2 & $\mathbf{3}$ & 3 \\
\hline
\end{tabular}

Katılımcıların ağırlıklı olarak değer ve bağlam değişikliklerini tercih etmelerinin bir eğilim olmaktan ziyade yöntem ve stratejiyi değiştirerek yeni sorular üretmedeki zihinsel yetersizliklerinden kaynaklandığı görülmüştür. Örneğin, Nihal bağlam değiştirme ve basitleştirme tekniklerini kullanarak kaynak soruyla çözüm yöntemi ve stratejisi açısından hiçbir fark1 olmayan üç adet soru üretmiştir. Çözüm yönteminde değişiklik yapması istendiğinde yetersiz kalmış ve bu yetersizliğinin farkında olduğunu açıkça ifade etmiştir. 


\section{Diyalog 1:}

Nihal: Muslukları [musluk sorularını] hiç sevmem... Kitap okumayı severim, kitap okumak diyelim. Mesela Pınar 10 günde 3 kitap okusun Derya da 15 günde 5 kitap okusun, kitap okuma hızlarını karşılaştırınız.

Araştırmacı: Burada sorudaki neleri değiştirdik?

Nihal: Aslında bir şey değiştirmedik; sadece yapılan işle ne kadar sürede yapıldığını değiştirdik, onun dışında aynı şekilde, çözüm yöntemi aynı. ...

Araştırmacı: Farklı yöntemle çözülebilecek bir soru oluşturabilir misin?

Nihal: I11... [bağlam değiştirerek bir hız problemi oluşturuyor]... Yine bir oran orantı sorusu olacak ama biraz daha düşünmek istiyorum... Getiremedim sonunu... Soru oluşturmak zor. Çünkü belli başlı şeyler geliyor aklıma, onlar da yeterince yaratıcı şeyler olmuyor...

Yeniden düzenleme kapsamında kullanılan bir diğer problem kurma durumu ise nitel kıyaslamalar yapmayı gerektiren aşağıdaki soruyu içermektedir:

II. Durum: Ahmet her gün aynı pistte koşu yapmaktadır. Bugün dün koştuğundan daha fazla sürede daha az tur koşmuştur. Buna göre dünkü ve bugünkü hızlarını karşıllaştırınız.

Katılımcıların başarısında genel bir düşüş gözlenmiştir. Yaklaşık dörtte birlik kısmı ya hiç problem üretememiş ya da mantık hatası ve eksik bilgi içeren sorular üretmiştir (Tablo 3). Örneğin, yanıtını içinde barındırdığg için aşağıdaki problem mantık hatası içerenler kategorisinde değerlendirilmiştir:

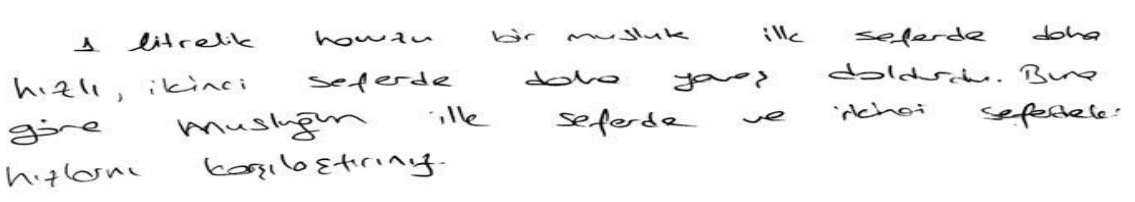

Alıntı 5. Mantık hatası içeren problem örneği [ÖA-61] 
Tablo 3. II. Problem kurma durumuna ilişkin yazılı sınav analiz sonuçları.

\begin{tabular}{|c|c|c|c|}
\hline \multicolumn{2}{|c|}{ Kullanılan Yöntem } & Frekans & Yüzde \\
\hline \multicolumn{2}{|l|}{ Değer değiştirme } & 8 & 4.9 \\
\hline \multicolumn{2}{|l|}{ Bağlam değiştirme } & 46 & 28.4 \\
\hline \multicolumn{2}{|l|}{ Basitleştirme } & 12 & 7.4 \\
\hline \multicolumn{2}{|l|}{ Genişletme } & 3 & 1.9 \\
\hline \multicolumn{2}{|l|}{ Sayısal veri ekleme } & 9 & 5.6 \\
\hline \multicolumn{2}{|l|}{ Kombinasyon } & 24 & 21.1 \\
\hline \multicolumn{2}{|l|}{ Yapısal değişim } & 17 & 10.5 \\
\hline \multirow{3}{*}{$\begin{array}{l}\text { Değerlendirmeye } \\
\text { alınmayanlar }\end{array}$} & Yetersiz bilgi & 9 & 5.6 \\
\hline & Mantık hatası & 29 & 17.9 \\
\hline & Yanit yok & 5 & 3.1 \\
\hline \multicolumn{2}{|l|}{ Toplam } & 162 & $\% 100$ \\
\hline
\end{tabular}

Dikkat çeken bir diğer husus ise sadece 17 öğretmen adayının kaynak soru üzerinde yapısal değişikliğe gidip farklı yöntem ve stratejilerle çözülebilecek problemler oluşturmuş olmasıdır. Aşağıda bir örneği görülen bu tür soruların temel karakteristiği orantı düşüncesinin problem durumunun özgün koşullarını karşılayacak şekilde adapte edilerek kullanımını gerektirmesidir.

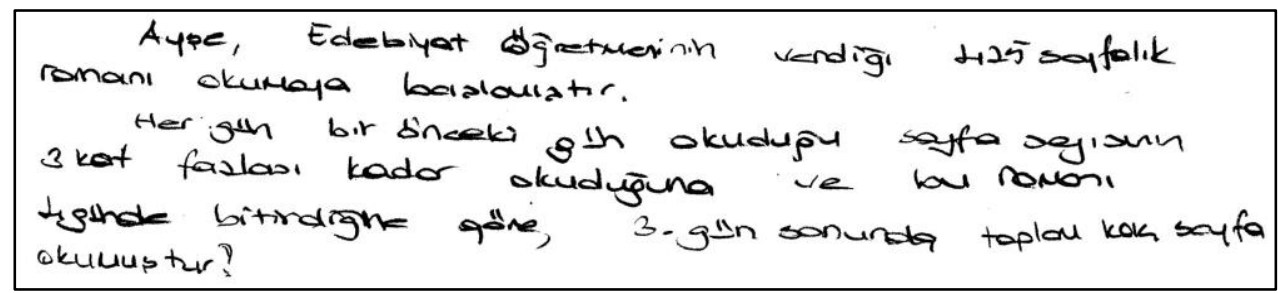

Alıntı 6. Yapısal değişiklik içeren problem örneği [ÖA-124]

$\mathrm{Bu}$ sorunun çözümü orantısal akıl yürütmenin ardışık günler bağlamında ve peşi peşine kullanımını içermektedir ki bu durum problem çözücüye yeni bir zihinsel yük getirmektedir. Ayrıca, her ne kadar nitel karakterli kaynak soru nicel bir karaktere dönüştürülmüş olsa da üretilmiş olan problemin çözümünde cebirsel denklem yazma, problem durumunu görsel araçlarla modelleme ve geriye doğru çalışma gibi farklı stratejiler de kullanılabilir. Geri kalan katılımcıların bir önceki problem kurma durumunda olduğu gibi bağlam değiştirme, değer değiştirme ve basitleştirme türünden rutin teknikleri kullandıkları görülmektedir. Kombinasyon kategorisi içinde yer alan 17 soruyla birlikte toplam 26 sorunun üretiminde sayısal veri kullanılmıştır ki bu durum katılımcıların nicel muhakeme bağımlılıklarının göstergesi olarak yorumlanabilir. Buna ilişkin sayısal veri ekleme tekniği kullanılarak üretilmiş örnek bir problem şu şekildedir:

"Mustafa her gün düzenli olarak spor yapmaktadır. Hafta içi okula gitmeden $20 \mathrm{dk}$ koşarak evin etrafinda 10 tur atmaktadır. Hafta sonları ise 30 dk koşarak 17 tur attığına göre hafta içi ve hafta sonu hızlarını karşılaştırınız”. [ÖA-127] 
Görüşmede üretilen 19 problemden bir tanesi dışında geri kalanların matematiksel açıdan doğru olduğu görülmüsstür (Tablo 4). Bunlardan 5 tanesi yapısal değişiklikler içerirken - farklı yöntem ve stratejilerle çözülebilen sorular iken - 13 tanesinin rutin teknikler kullanılarak oluşturulduğu görülmüştür. Üretilen soruların yaklaşık yarısında sayısal değerler kullanılmıştır. Aşağıdaki diyalogdan bunun nedeninin kaynak sorunun doğasında var olan soyutluğu giderip daha kolay kılma çabasından kaynaklandığı anlaşılmaktadır.

\section{Diyalog 2:}

Araştırmacı: Neden sayısal veri kullanmayı tercih ettin?

Nihal: Bize verilen soruda belli bir süre yoktu; 1 saat ya da 1 dakika gibi. Yapılan işin miktarı hakkında da bir bilgi yoktu. Sayısal değerler kattım soruya; daha somut hale geldi; ilkine göre kolay bir soru oldu. Öğrenci bir soruyu okuduğu zaman hiç veri yoksa ona değer vermesi gerekiyor. Örneğin, V hızı ya da A kg gibi. Sayısal veri içermeyen soru oluşturmak da zor. Benim bugüne kadar gördüğüm problemlerin çoğunda sayısal değerler vardı.

Nihal'in ifadelerinden nitel kıyaslamalar içeren soru oluşturmada zorlandığı açıkça anlaşılmaktadır. Son cümlede söyledikleri ise geçmişte aldıkları eğitimin ve takip ettikleri öğretim kaynaklarının temel karakteristiğini yansıtması açısından önemlidir.

Tablo 4. II. Problem kurma durumuna ilişkin görüşme bulguları

\begin{tabular}{|c|c|c|c|c|c|c|c|c|}
\hline Kullanılan Yöntem Katılımcılar &  & $\frac{\stackrel{\mathscr{N}}{\pi}}{\pi}$ &  & $\frac{\grave{d}}{\frac{2}{2}}$ & $\underset{=}{\mathscr{y}}$ & 芯 & 胥 & 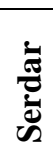 \\
\hline Bağlam değiştirme & & $\mathrm{x}$ & & $\mathrm{x}$ & & & & $\mathrm{x}$ \\
\hline Basitlestirme & & & & & & & $\mathrm{x}$ & \\
\hline Sayısal veri ekleme & $\mathrm{x}$ & & $\mathrm{XX}$ & & & $\mathrm{XX}$ & $\mathrm{xx}$ & $\mathrm{x}$ \\
\hline Kombinasyon & & $\mathrm{x}$ & & & & & & \\
\hline Yapısal değişim & & & & & $\mathrm{xxx}$ & & & $\mathrm{xx}$ \\
\hline Değerlendirmeye alınmayanlar & $\mathrm{x}$ & & & & & & & \\
\hline Toplam & 2 & 2 & 2 & 1 & 3 & 2 & 3 & 4 \\
\hline
\end{tabular}

Araştırmada kullanılan 5 adet yarı-yapılandırılmış problem kurma durumunun temel özelliği kuracakları problemler için katılımcılara esin kaynağı olacak genel bir bağlam sunmasıdır. Analiz sonuçları katılımcıların problem kurmadaki başarılarının ve bu süreçte kullandıkları yöntem, teknik ve düşüncelerin verilen problem kurma durumlarının bağlamsal özelliklerine göre değiştiğini göstermektedir. Bağlamsal özellikler problem kurma durumunun soyutluk düzeyi (problem kurma durumunun bir şekille mi, modelle mi yoksa cebirsel ifadeyle mi verildiği gibi hususlar), veri seti içerip içermediği, orantı 
kavramını ve ilgili algoritmaları (içler-dışlar çarpımı gibi) ne düzeyde çağrıştırdığı ve katılımcıların geçmiş öğrenim tecrübeleriyle olan ilişki düzeyi gibi parametrelerden oluşmaktadır. Gerçek yaşam pratiğinde tecrübe ettikleri veya orantı kavramını çağrıştıran iki oranın eşitliği şeklinde yazılmış bir cebirsel durumdan hareketle problem oluşturmada katılımcıların oldukça başarılı oldukları görülmüştür. Örneğin, yazılı sınavda $\frac{x}{x+9}=\frac{2}{5}$ durumuyla alakalı 123 (\%76) öğretmen adayının matematiksel açıdan mantıklı sorular oluşturduğu, bunların 117 tanesinin doğru orant1, 6 tanesinin ise ters orantı düşüncesini içerdiği görülmüştür. Benzer şekilde gerçek yaşamda tecrübe ettikleri ve nicel veriler içeren pasta tarifini içeren durumdan hareketle oluşturulan sorulardan $114(\% 70)$ tanesinin orantısal akıl yürütme gerektiren problemler olduğu görülmüsstür (Tablo 5). Bir tanesi hariç kurulan problemlerin tamamının doğru orantı düşüncesini içerdiği tespit edilmiştir.

III. Durum: Aşağıda pasta yapımında kullanılan malzemelerin listesi verilmiştir. $B u$ durumdan hareketle orantısal akl yürütmeyle çözülebilecek bir problem kurunuz.

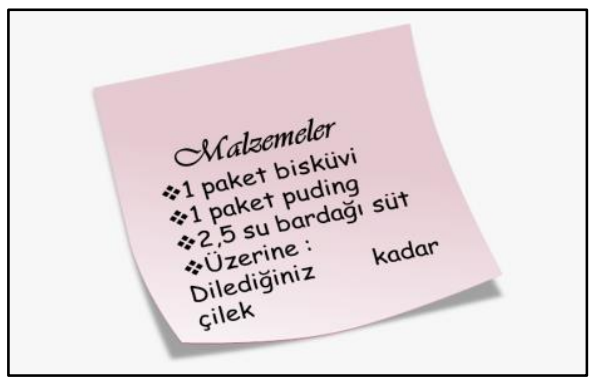

Tablo 5. III. Problem kurma durumuna ilişkin yazılı sınav analiz sonuçları

\begin{tabular}{|c|c|c|c|}
\hline \multicolumn{2}{|c|}{ Oluşturulan Problemlerin Türü } & Frekans & Yüzde \\
\hline \multirow{2}{*}{$\begin{array}{l}\text { Orantısal akıl yürütme } \\
\text { gerektiren problemler }\end{array}$} & Niceliksel karşılaştırma & 1 & 0.6 \\
\hline & Doğru orant1 & 113 & 69.8 \\
\hline \multirow{2}{*}{$\begin{array}{l}\text { Farklı konularda } \\
\text { olușturulmuș problemler }\end{array}$} & Oran problemleri & 6 & 3.7 \\
\hline & Dört işlem problemleri & 7 & 4.3 \\
\hline \multirow{4}{*}{$\begin{array}{l}\text { Değerlendirmeye } \\
\text { alınmayanlar }\end{array}$} & İfadeye uygun olmayan problemler & 14 & 8.6 \\
\hline & Yetersiz bilgi & 11 & 6.8 \\
\hline & Mantık hatas1 & 7 & 4.3 \\
\hline & Yanit yok & 3 & 1.9 \\
\hline \multicolumn{2}{|l|}{ Toplam } & 162 & $\% 100$ \\
\hline
\end{tabular}

Problem kurma durumu bağlamsal özellikleri itibariyle soyutlaştıkça ve yoruma açık bir hal aldıkça katılımcıların zorlandıkları görülmüştür. Örneğin, yöntem bölümünde verilen ve sadece bir araba resmi içeren (bakınız, Şekil-1) yarı-yapılandırılmış problem kurma durumuna ilişkin oluşturulan problemlerin ancak yarısının orantısal akıl yürütme içerdiği ve matematiksel açıdan doğru olduğu görülmüştür. Dikdörtgen şeklinde 
karolardan oluşan aşağıdaki modelden hareketle problem üretebilenlerin oranı \%30'lara kadar düşmüştür.

IV. Durum: Aşağıdaki modelin temsil ettiği bilgi ve ilişkilere bă̆ll kalarak orantısal akıl yürütmeyle çözülebilen bir problem oluşturunuz. (Not: Birimler aynı büyüklüktedir).

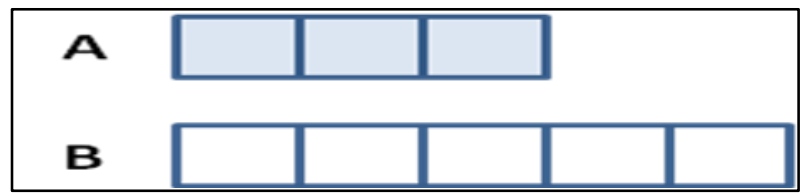

Tablo 6. IV. Problem kurma durumuna ilişkin yazılı sınav analiz sonuçları.

\begin{tabular}{|c|c|c|c|}
\hline \multicolumn{2}{|c|}{ Oluşturulan Problemlerin Türü } & Frekans & Yüzde \\
\hline \multirow{3}{*}{$\begin{array}{l}\text { Orantısal akıl yürütme } \\
\text { gerektiren problemler }\end{array}$} & Niceliksel karşılaștırma & 14 & 8.7 \\
\hline & Doğru orantı & 37 & 22.8 \\
\hline & Ters orant 1 & 3 & 1.9 \\
\hline \multirow{5}{*}{$\begin{array}{l}\text { Farklı konularda } \\
\text { oluşturulmuş problemler }\end{array}$} & Oran problemleri & 18 & 11.1 \\
\hline & Kesir problemleri & 6 & 3.7 \\
\hline & Denklem problemleri & 9 & 5.6 \\
\hline & Dört işlem problemleri & 21 & 13 \\
\hline & Geometri & 2 & 1.2 \\
\hline \multirow{4}{*}{$\begin{array}{l}\text { Değerlendirmeye } \\
\text { alınmayanlar }\end{array}$} & İfadeye uygun olmayan problemler & 26 & 16 \\
\hline & Yetersiz bilgi & 11 & 6.8 \\
\hline & Mantık hatası & 9 & 5.6 \\
\hline & Yanit yok & 6 & 3.7 \\
\hline \multicolumn{2}{|l|}{ Toplam } & 162 & $\% 100$ \\
\hline
\end{tabular}

Tablo 6'da görüldüğüü üzere katılımcıların üçte biri farklı konu ve kavramlarla alakalı sorular oluşturmuştur. $\mathrm{Bu}$ bağlamda en fazla dört işlem ve oran kavramını içeren problemlerin kurulduğu görülmektedir. Özellikle oran kavramını kullanan öğrencilerin söz konusu düşünceyle orantı arasında var olan ince ama bir o kadar da önemli anlamsal fark1 göz ardı ettikleri açıktır. Oluşturulan problemlerin yaklaşık üçte birlik kısmı değerlendirmeye alınmamıştır. Bunların bir kısmı eksik bilgi ve mantık hataları içerirken bir kısmının da verilen modelle içeriksel açıdan uyumlu olmayan sorular olduğu görülmüştür. Örneğin, aşağıdaki problemin matematiksel olarak doğru olmakla birlikte verilen modelle anlamsal tutarlılık içermediği açıktır. 




Alıntı 7. Verilen model ile uyumlu olmayan problem örneği [ÖA-13]

Öğretmen adaylarının görüşmelerde kurdukları problemlerin yaklaşık yarısının farklı kavramları konu edindiği; verilen problem kurma durumunun içeriğiyle tutarsızlık arz ettiği ya da eksik bilgi içerdiği görülmüştür (Tablo 7). Görüşme sonuçlarının detaylı analizi bu durumun çoğunlukla verilen modeller arasındaki orantısal ilişkinin anlaşılamamasından veya yapılan çıkarımların doğru kullanılamamasından kaynaklandığını göstermektedir.

Tablo 7. IV. Problem kurma durumuna ilişkin görüşme bulguları

\begin{tabular}{|c|c|c|c|c|c|c|c|c|c|}
\hline Kullanılan Yönt & Katılımcılar & $\underset{\Xi}{\tilde{E}}$ & $\frac{\mathbb{\tilde { N }}}{\mathbb{\pi}}$ & 苞 & $\frac{\grave{d}}{\grave{Z}}$ &  & 芯 & 焉 &  \\
\hline & Niceliksel karşılaştırma & & $\mathrm{x}$ & & & & & & $\mathrm{x}$ \\
\hline $\begin{array}{l}\text { Urantisal ak1l } \\
\text { vërïtme iceren }\end{array}$ & Doğru orantı & $\mathrm{X}$ & $\mathrm{x}$ & $\mathrm{xx}$ & & & & & \\
\hline $\begin{array}{l}\text { yurutme içeren } \\
\text { nroblemler }\end{array}$ & Ters orant1 & & & & & $\mathrm{x}$ & & $\mathrm{x}$ & \\
\hline & Bileşik orantı & $\mathrm{xx}$ & & & & & & & \\
\hline Farklı konularda & Oran problemleri & $\mathrm{X}$ & $\mathrm{x}$ & & $\mathrm{x}$ & & $\mathrm{x}$ & & \\
\hline oluşturulmuş & Kesir problemleri & & & & & & $\mathrm{x}$ & & \\
\hline problemler & Dört işlem problemi & & & & & $\mathrm{x}$ & & & \\
\hline Değerlendirmeye & $\begin{array}{l}\text { İfadeye uygun olmayan } \\
\text { problemler }\end{array}$ & & $\mathrm{X}$ & & & & & & \\
\hline & Yetersiz bilgi & $\mathrm{XXX}$ & & & $\mathrm{x}$ & & & & \\
\hline Toplam & & 7 & 4 & 2 & 2 & 2 & 2 & 1 & 1 \\
\hline
\end{tabular}

Örneğin, görüşme esnasında verilen durumu kesir gibi algılayıp ona uygun problem oluşturan Sami durumu şu şekilde ifade etmiştir:

\section{Diyalog 3:}

Sami: ... Kesir gibi düşündüm. Bir parçanın 8'e bölümü olarak düşündüm. Mehmet bir pastayı 8'e bölmüştür 3 ünü yiyecek gibi. A sayıs1 75 olsun. B sayıs1 da 75 olsun. Bunların bir parçası ne kadardır? Yani A'yı 3 e bölmüş; tek parçası 25 yapar. B'yi 5 e bölmüş tek parçası 15 yapar mesela. ... 
Araştırmacı: Verilen modeli orantı kavramıyla ilişkilendirerek düşünsen nasıl bir soru oluşturursun?

Sami: Şu olabilir. A’nın B’ye oranı kaçtır?

Araştırmacı: ... Şimdi şöyle düşünelim bu modelde bir bilgi var. A çokluğu 3 birim, B çokluğu da 5 birim diyor. Bu aslında 3'e 5 oranını ifade ediyor; senden bu ilişkiyi esas alan bir orantı problemi kurmanı istiyorum.

Sami: Mesela biri un olsun, biri su olsun. İkisi de $75^{\prime} \mathrm{er} \mathrm{kg}$ olsun. A un diyorum ve A'yı üçe bölüyorum. Suyu da 5'e bölüyorum. Hani mesela pilav pişirirken 1 e 3 oranı var ya onun gibi. A'dan bir parça B'den iki parça aldığımız zaman ekmek yapabiliyorum. A'dan bir parça aldığım zaman kaç yapıyor? 25 yapıyor. B'den iki parça almış olsam 50 yapacak. Tamamlayamadım soruyu... Zaten yine kesir gibi düşündüm; hep kesir konusuna gidiyorum. Başka şekilde aklıma gelmiyor.

Diyalogdan Sami'nin verilen modeli kesir olarak algıladığı, araştırmacının ısrarla orantısal akıl yürütme sorusu oluşturmasını istemesine rağmen bunu başaramadığı görülmektedir.

Bulgular, katılımcıların serbest problem kurma durumlarından hareketle ve istenilen özelliklerde yeni problemler oluşturmada çok daha fazla zorlandıklarını göstermiştir. Bu kategoride 'Orantısal akıl yürütme gerektiren ve çözümünün zor olduğunu


sorular iki farklı açıdan analiz edilmiştir. İlk olarak üretilen soruların orantı kavramıyla ilişkili olup olmadığı, içerdiği düşünce türleri ve kullanılan verilerin karakteristiği gibi farklı parametreler esas alınarak genel bir analizi yapılmıştır. Yazılı sınavda üretilen problemlerden \%43'ünün orantısal akıl yürütme içerdiği, geri kalanların büyük çoğunluğunun farklı konu ve kavramlarla alakalı olduğu görülmüştür (bakınız, Tablo 8).

Tablo 8. V. Problem kurma durumuna ilişkin yazılı sınav analiz sonuçları

\begin{tabular}{l|l|c|c}
\hline \multicolumn{2}{c|}{ Oluşturulan Problemlerin Türü } & Frekans & Yüzde \\
\hline \multirow{3}{*}{$\begin{array}{l}\text { Orantısal akıl yürütme } \\
\text { içeren problemler }\end{array}$} & Niceliksel karşılaştırma & 9 & 5.6 \\
\cline { 2 - 4 } & Doğru orant1 & 12 & 7.4 \\
\cline { 2 - 4 } & Ters orant1 & 16 & 9.9 \\
\cline { 2 - 4 } & Bileşik orant1 & 31 & 19.1 \\
\hline \multirow{3}{*}{$\begin{array}{l}\text { Farklı konularda } \\
\text { oluşturulmuş problemler }\end{array}$} & Oran problemleri & 8 & 4.9 \\
\cline { 2 - 4 } & Kesir problemleri & 4 & 2.5 \\
\cline { 2 - 4 } & Denklem problemleri & 47 & 6.2 \\
\cline { 2 - 4 } & Dört işlem problemi & 13 & 8 \\
\hline \multirow{2}{*}{$\begin{array}{l}\text { Değerlendirmeye } \\
\text { alınmayanlar }\end{array}$} & Yetersiz bilgi & 4 & 2.5 \\
\cline { 2 - 4 } & Mantık hatas1 & 8 & 4.9 \\
\cline { 2 - 4 } & Yanit yok & $\mathbf{1 6 2}$ & $\mathbf{\% 1 0 0}$ \\
\hline Toplam & & & \\
\hline
\end{tabular}


Bulgular, orantısal akıl yürütme becerisi gerektiren soruların niteliğinin bilgi, uygulama ve muhakeme (TIMSS, 2011) soruları şeklinde farklılaştığını göstermektedir. Tablo 9'da katılımcıların \%10'unun bilgi soruları ürettiği görülmektedir ki bu sorular ezber bilgilerin ve kavram tanımının direkt kullanımıyla çözülebilen problemleri içermektedir.

Tablo 9. V. Problem kurma durumuna ilişkin üretilen soruların zorluk derecelerine göre dağılımı

\begin{tabular}{lcc}
\hline Soru Düzeyi & Frekans & Yüzde \\
\hline Bilgi soruları & 7 & 10.3 \\
Uygulama soruları & 46 & 67.6 \\
Muhakeme soruları & 15 & 22.1 \\
\hline Toplam & $\mathbf{6 8}$ & $\mathbf{1 0 0}$ \\
\hline
\end{tabular}

Orantı kavramıyla alakalı işlemsel bilgilerin (içler-dışlar çarpımı algoritması, aritmetiksel işlemler, vs.) işe koşulmasıyla çözümü kolayca yapılabilen problemler uygulama sorusu olarak değerlendirilmiştir ki katılımcıların büyük çoğunluğunun bu tür problemler oluşturdukları görülmektedir. Nitel çokluklar arasındaki çarpımsal ilişkiyi konu edinen, muhakeme temelli yordamalar yapmayı ve yeni yargılara ulaşmayı zorunlu kılan, ilişkili olduğu bağlamın özellikleri gereği bilgiyi uyarlayarak kullanmayı gerektiren problemler ise muhakeme sorusu olarak belirlenmiştir. Bu nedenle bilgi ve uygulama sorularına kıyasla muhakeme sorularının daha üst düzey düşünebilme yeteneği gerektirdiği söylenebilir. Orantısal akıl yürütme gerektiren ve matematiksel olarak doğru kabul edilen soruların \%22'sinin bu tür sorular olduğu, ancak tüm katılımcılar bazında bu oranın \%9 gibi oldukça düşük bir kesimi içerdiği görülmektedir. Muhakeme sorusu kategorisinde değerlendirilen örnek bir yanıt şu şekildedir:

"Elimizde aynı büyüklükte sarı ve yeşil limonlar vardır. Sarı limonlar ekşi, yeşil limonlar ise tatlıdır. 4 sarl limon ve 3 yeşil limonla elde ettiğimiz karışım mi yoksa 9 sarı limon ve 7 yeşil limonla elde ettiğimiz karışım mı daha ekşidir?” [ÖA-4]

Muhakeme soruları oluşturmada görüşmeye katılan öğretmen adaylarının da zorlandıkları görülmüştür. Katılımcıların yarısı hiçbir soru üretememiş; geri kalan dört öğretmen adayı ise toplam 5 adet problem oluşturmuştur. Bu sorulardan bir tanesinin eksik bilgi içerdiği, doğru kabul edilen 4 sorudan birinin ters orantı, üçünün ise bileşik orantı kavramıyla alakalı olduğu görülmüştür. Katılımcıların sorunun zorluk derecesini belirleyen temel unsur olarak ortamda bulunan değişken sayısını gördükleri anlaşılmıştır. Öğretmen adayları, işlemsel bilgiler ve algoritma yardımıyla kolayca çözülebildiği için doğru ve ters orantı sorularını kolay sorular; buna karşılık ikiden fazla çokluk arasındaki çarpımsal ilişkilerin tespitini gerektirdiği için bileşik orantı sorularını zor sorular olarak gördüklerini ifade etmişlerdir. Bu durum Alper isimli öğrencinin sözlerinden açıkça anlaşılmaktadır: 


\section{Diyalog 4:}

Alper: Doğru orantı ve ters orantı sorularını öğrenciler yapabiliyorlar... Yani işlemsel bilgileri yeterince var bunları çözmek için. Ama bileşik orantı sorularında [çokluklar arasında] mukayese yapamıorlar; dolayısıyla bunlarda zorlanıyorlar. .... Aralarında doğru orant1 $\mathrm{m} 1$ kuracak, yoksa ters orantı m1 kuracak, bunu belirlemekte sıkıntı yaşayacaklarını düşündüğüm için böyle bir soru hazırladım.

\section{Tartışma ve Sonuç}

$\mathrm{Bu}$ çalışmada ilköğretim matematik öğretmeni adaylarının problem kurma becerileri 'yeniden düzenleme, yarı-yapılandırılmış ve serbest problem kurma durumları' bağlamında incelenmiştir. Bulgular öğretmen adaylarının oluşturdukları problemlerin niteliği ve bu süreçte kullandıkları tekniklere ilişkin önemli bilgiler vermektedir. Çalışmanın ortaya koyduğu en temel sonuç katılımcıların yeniden düzenleme durumlarıyla alakalı problem oluşturmada başarılı olmalarına karşın aynı yeterliği yarıyapılandırılmış ve serbest problem kurma durumlarında gösteremedikleri gerçeğidir. Bunun, düşüncenin doğası ve bilginin içeriğiyle alakalı bir durum olduğu söylenebilir. Yoğun bilişsel eylemler gerektiren, üretkenlik ve yaratıcılık isteyen, matematiksel içeriğin yanı sıra problem hikâyesinin oluşturulmasını da zorunlu kılan yarı-yapılandırılmış ve serbest problem kurma durumlarına kiyasla ortamda var olan model bir sorudan esinlenerek veya üzerinde değişiklikler yaparak yeni soruların üretilmesi çok daha kolay olsa gerektir (Stickles, 2006).

Yeniden düzenleme durumunda, sürecin başında verilen kaynak soru, problem kurucu için bir düşünme aracı olarak işlev görmektedir. Problem kurucuya esin kaynağ teşkil eden mantık ve muhteva, çözüm yöntemi ve stratejiler kaynak soruda bulunmaktadır. Problem çözücünün yapması gereken verilen problemi analiz ederek söz konusu alanlara ilişkin tespit ve çıkarımlarda bulunmak, sonrasında ise bunlar üzerinde düzenlemeler yaparak yeni problemler üretmektir. Bunun yarı-yapılandırılmış veya serbest problem kurma durumlarına kıyasla çok daha az bilişsel çaba ve gayret gerektirdiği açıktır. Benzer bulgu ve yorumlar daha önce yapılmış çalışmalarda da görülmektedir (Stickles, 2006). Yeniden düzenleme durumlarındaki başarının bir başka sebebi olarak katılımcıların geçmiş öğrenim tecrübelerinden bahsedilebilir. Bilindiği üzere yeniden düzenleme yoluyla problemler oluşturmak ilköğretimden üniversiteye kadar eğitim-öğretim sürecinin her kademesinde sıklıkla kullanılan bir tekniktir. Öğretmenler, ellerindeki bir problemin çözümünü yaptıktan sonra söz konusu problem içerisindeki sayısal verileri değiştirerek yeni problemler üretirler ve öğrencilerinden çözmelerini isterler. Pedagojik açıdan sağlıklı olmasa da buradaki amaç benzer sorular üzerinde çalıştırarak öğrencilerin metot ve strateji bilgilerini pekiştirmektir. $\mathrm{Bu}$ çalışmada yer alan katılımcıların benzer bir eğitim 
sürecinden geçtikleri düşünülürse, yeniden düzenleme sorularında öğretmen adaylarının büyük çoğunluğunun gösterdiği başarının sebebi daha iyi anlaşılabilir.

Katılımcıların yeniden düzenleme kategorisindeki problem kurma durumlarına ilişkin başarılarının kendi içinde değişkenlik arz ettiği görülmüştür. $\mathrm{Bu}$ durumun, kaynak sorunun soyutluk düzeyiyle alakalı olduğu söylenebilir. Nicel mukayeseler gerektiren durumlara kıyasla nitel çokluklar arasındaki çarpımsal ilişkileri konu edinen problem durumlarından hareketle yeni sorular oluşturmada daha fazla zorlandıkları görülmektedir. $\mathrm{Bu}$ açıdan eldeki çalışma daha önceki araştırma sonuçlarını destekler bulgular ortaya koymuştur (Leung \& Silver, 1997). Görüşmelerden elde edilen bulgular, bu zorluğun temel sebeplerinden bir tanesi olarak yine katılımcıların geçmiş öğrenim tecrübelerini işaret etmektedir (bakınız, Diyalog 2). Bu çalışmanın önemli sonuçlarından biri de yeniden düzenleme durumlarıyla alakalı problem kurma sürecinde sergilen düşünce eğilimleri ve kullanılan tekniklere ilişkindir. Katılımcıların ağırlıklı olarak nicel muhakemeyi işe koşarak problemler oluşturmaya çalıştıkları görülmüştür. Örneğin, I. problem kurma durumundan hareketle yeni sorular üretirken çok az sayıda katılımcının kaynak soru üzerinde yapısal değişime gittiği görülmüştür. Bu öğretmen adayları, kaynak sorunun çözümünde takip edilen yaklaşım ve stratejilerde değişime giderek orantısal muhakemenin farklı şekillerde yürütülmesini gerektiren ve özgünlük içeren sorular üretebilmişlerdir. Geri kalanların, değer değiştirme, bağlam değiştirme, sayısal veri ekleme ve basitleştirme türünden rutinlere yöneldikleri ve sonuçta kaynak soruyla içerik ve çözüm yolu itibariyle eşdeğer problemler oluşturdukları görülmüştür. İkinci problem kurma durumunda, katılımcıların ancak onda biri yapısal değişimler içeren yeni sorular üretebilirken, büyük çoğunluğun bağlam değiştirmeye yöneldiği veya sayısal veriler atayarak nitel karakterli soruyu nicele dönüştürmeye çalıştığ 1 görülmüştür. Özetle, yazılı sınav ve görüşme bulguları katılımcıların kaynak sorunun içeriğine ve çözüm yoluna sıkı sıkıya bağlı kaldıklarını, nicel muhakeme içeren problemler oluşturduklarını göstermektedir.

Bulgular, yarı-yapılandırılmış problem kurma durumlarında başarıyı etkileyen temel faktörlerin katılımcıların geçmiş öğrenim yaşantıları, problem kurma durumunun gerçek yaşamla ilişki düzeyi ve problem kurma durumunun nicel-nitel yapısı olduğunu işaret etmektedir. Çünkü problem kurma durumları, problem kurucunun geçmiş öğrenim tecrübelerinden uzaklaştıkça ve soyutluk düzeyi arttıkça başarının düştüğü görülmektedir. İki oranın eşitliğini içeren ve içler-dışlar çarpımı algoritmasını çağrıştıran bir ifade verildiğinde katılımcıların dörtte üçlük kesiminin orantısal akıl yürütme gerektiren ve matematiksel açıdan doğru sorular ürettikleri görülmüştür. Gerçek yaşamdan aşina oldukları ve sayısal veriler içeren pasta tarifi sorusunda da yine katılımcıların büyük çoğunluğu uygun sorular oluştururken araba resmi içeren durumdan hareketle problem oluşturabilenlerin oranında ciddi bir düşüş yaşanmıştır. Aslında araba resmi içeren problem kurma durumu, bayan-erkek tüm katılımcıların hemen her gün tecrübe ettikleri bir gerçek yaşam durumuyla yakından alakalıdır. Ayrıca, ortaokul yıllarından itibaren hızzaman-yol değişkenleri arasındaki orantısal ilişkileri konu edinen çok sayıda problem çözmüş oldukları da bir gerçektir. Buna rağmen, araba sorusunda başarının düşmesinin tek mantıklı izahı ortamda sayısal verilerin bulunmayışıdır. Gerçek yaşamdan kopuk ve 
sayısal veriler içermeyen, sadece dikdörtgen şeklinde karolardan oluşan bir modelden hareketle problem üretebilenlerin oranının toplam katılımcıların üçte birinden daha az olduğu görülmektedir. Dikkat çeken bir diğer önemli husus ise yarı-yapılandırılmış problem kurma durumlarından hareketle üretilen problemlerin tamamına yakınında nicel verilerin kullanılması ve doğru orantı düşüncesinin işe koşulmasıdır. Bu durum da yine katılımcıların geçmişte tecrübe ettikleri soru türlerine ve rutinlere bağlı kaldıklarının göstergesi olarak yorumlanabilir.

Serbest problem kurma durumlarının, katılımcıların bu alandaki yeterliklerinin en yalın haliyle ve tüm boyutlarıyla gözlemlenmesi için uygun ortamlar sunduğu açıktır. $\mathrm{Bu}$ kategoride, katılımcıların yarıdan daha az bir kısmı anlamlı sorular üretebilmiştir. Oluşturulan problemlerin büyük çoğunluğunun ise nicel muhakeme gerektiren ve bilinen kuralların işe koşulmasıyla çözülebilen uygulama soruları olduğu görülmüştür. Bu süreçte katılımcılar kendi yaşantılarından ve gerçek yaşam durumlarından esinlenmişlerdir ki bu durum geçmiş deneyimlerin ve sosyo-kültürel çevrenin problem kurucu üzerindeki etkileri olarak değerlendirilebilir (Stickles, 2006). Yakından bakıldığında gerçek yaşamda kullanılan enstrümanların sorunun hikâyesiyle alakalı olduğu; esasa ilişkin - üretilen problemin soyutluk düzeyi, içerdiği muhakeme türü, özgün çözüm yolları ve farklı stratejiler gerektirmesi, gerçek yaşam koşullarını karşılamak için orantısal akıl yürütmenin uyarlanarak kullanılması - bir zenginlik ve derinlik sağlamadığı anlaşılmaktadır. Katılımcıların bileşik orantı düşüncesini içeren soruları zor soru olarak kabul ettikleri; bu düşünceyi kullanarak işçi ve havuz problemleri türünden sorulara yöneldikleri görülmüştür. $\mathrm{Bu}$ sonuçlar, öğretmen adaylarının problemlerin içeriğini oluştururken geçmiş öğrenim yaşantılarından, bağlam ve hikâye kısmını oluştururken ise gerçek yaşam tecrübelerinden yararlandıkları şeklinde yorumlanabilir.

Özetle, katılımcıların nicel muhakemeyi önceleyen, bilinen kurallarla çözülebilen, yapısı ve çözüm yolu itibariyle ders kitaplarındaki alıştırma türünden sorulara oldukça benzer problemler üretmede başarılı oldukları söylenebilir. Ancak, karşılaşılan bir durumun problem olabilmesi için çözüm yolunun açı olmaması, zihni zorlaması, bilişsel dengeyi bozması ve problem çözücüyü yeni arayışlara sevk etmesi gerekir (Van de Walle, Karp, Bay \& Williams, 2012). Bu açılardan bakıldığında ise öğretmen adaylarının problem kurma yeterliklerinin oldukça zayıf olduğu söylenebilir. Çünkü yaratıcılık isteyen, zihni zorlayan, farklı stratejilerle çözülebilen, orantısal akıl yürütmenin uyarlanarak kullanılmasını gerektiren sorular oluşturamadıkları görülmüştür. Problem kurma, problem çözmeyi de içeren daha üst düzey zihinsel eylemler sürecidir. Bu sürecin başarıyla yürütülebilmesi için üst-bilişin işe koşularak öz-takip ve öz-düzenlemelerin yapılması gerekir. Oluşturulan problemler içerisinde eksik bilgi ve mantık hatası içeren, matematiksel bağlamdan (orantısal akıl yürütme) kopuk, farklı konu ve kavramlarla alakalı soruların çokluğu dikkat çekmektedir. $\mathrm{Bu}$ durum öğretmen adaylarının oluşturdukları problemlerin doğruluğunu kontrol etmediklerinin ve kendi düşünceleri üzerinde akıl yürütmediklerinin açık göstergesidir. 
Sonuç olarak, öğretmen adaylarının problem kurma konusundaki yeterliklerini artırmak için alan ve alan eğitimi dersleri kapsamında problem kurma etkinlikleri üzerinde çalıştırılmaları önerilebilir. Bu yapılırken nitel karakterli yarı-yapılandırılmış ve serbest problem kurma durumları üzerinde çalıştırılmaları önem arz etmektedir. Bu süreçte, düşünceyi sınırlandırma ihtimali olan duruma özel teknik ve taktikler vermekten kaçınılmalıdır. Akıl tamamen özgür bırakılmalı, üst-bilişin işe koşulması ve yaratıcılığın önünün açılması için düşünceyi harekete geçiren açık uçlu sorularla problem kurucuya rehberlik yapılmalıdır. 


\section{Prospective Teachers' Proficiencies at Problem Posing in the Context of Proportional Reasoning}

\section{Extended Abstract}

Problem posing could be defined as the generation of a new problem from a situation or experience, or the reformulation of given problems (Duncer, 1945 cited in Abu-Elwan, 1999; Silver, 1994). It is considered as an effective way of doing mathematics (NCTM, 1989). It is suggested that problem posing-activities should be incorporated into mathematics curriculum and classroom practices (Kilpatrick, 1987; Moses, Bjork \& Goldenberg, 1990; NCTM, 1991; Brown \& Walter, 1993; Silver, 1994). The importance of problem posing has been recognized by the Turkish educators as well. The new elementary mathematics curriculum suggests that students should be engaged in problem posingactivities individually or as a group (MEB, 2013). The underlying philosophy of these suggestions is that problem posing activities support the development of mathematical reasoning in many different ways. If used properly, it promotes creativity, increases students' meta-cognitive skills and encourages their flexibility in thinking. When posing a problem students incorporate different methods and strategies, present their ideas through different representations and establish connections between mathematical notions. All these mental activities are likely to deepen and strengthen their knowledge of mathematics and, eventually, lead to the development of conceptual understanding.

Students' proficiencies in problem posing have been investigated in many studies. In the study of Leung and Silver (1997) prospective primary school teachers displayed better success in creating problems from situations that included numerical values; yet, they failed in situations that were abstract in nature. According to Stickles (2006) students' success fluctuates in accord with the structures of problem posing situations. In this study, prospective teachers performed better in generating problems from reformulation tasks; yet, they could not show the same proficiency in the semi-structured and free situations. Stickles explains this with the students' lack of knowledge and experiences in problem posing activities. Crespo and Sinclair (2008) explored prospective teachers' problem posing performances in the field of Euclid geometry and reported that only 6 tasks out of 133 were non-routine problems. The remaining were routine problems that could be manipulated procedurally. Similar results have been reported by Korkmaz and Gür (2006) who found that there was no difference in the quality of the problems posed by the prospective primary school teachers and prospective high school mathematics teachers. Problems generated by the two groups were very much similar to exercises and illustration tasks used in the mathematics textbooks. In summary, a review of available literature indicates that students from elementary school to university level encounter great difficulties in posing conceptually rich and cognitively challenging problems. Most students seem to be capable of generating problems that could be resolved by the application of rules, procedures and factual knowledge. However, they display lack of success in creating non-routine problems 
the solution of which requests adopting new approaches, using different methods and strategies, and incorporating creative and critical thinking.

This study examines prospective elementary school mathematics teachers' proficiencies in problem posing. The aim is to seek answer to the main research question that: 'How successful prospective elementary school teachers are in generating problems through reformulation tasks and from semi-structured and free situations?' Due to its unifying role in mathematics curriculum the notion of proportional reasoning has been taken as a mathematical context. So, we need to illustrate briefly the notion of proportional reasoning. Simply defined, proportional reasoning refers to an understanding of multiplicative relationship inherent in situations of comparison (Behr, Harel, Post \& Lesh, 1992; Cramer, Post \& Currier, 1993). It entails an ability to compare two quantities in relative (multiplicative) rather than absolute (additive) terms (Lamon, 1995). The multiplicative relationships between the quantities can be depicted in terms of a situation, for instance, If 10 cups of water fill one jug, how many cups of water do we need to fill four jug? In fact, proportional reasoning exceeds an understanding of multiplicative relationships between quantitative entities, and it entails conception of multiplicative relationships that exist in qualitative situations.

\section{Research Method}

The research employed qualitative inquiry (Yin, 2003) to examine the case in its natural setting. The participants were 162 students from mathematics education department in an Education Faculty in Turkey. Data were obtained from written exam and semi-structured interviews. First, a written exam was administered to the students. It included 10 problem posing situations. Three of them were about reformulation situations; five tasks were about semi-structured situations and two tasks were about free problem posing situations. In order to care validity and reliability issues data collection instruments were checked and revised through a pilot study. The written exam lasted in an hour during which students were encouraged to provide reasons for their answers. Semi-structured interviews were conducted with eight participants after the written exam. The interviewees were selected based on their performances in the exam. In the interviews, students were requested to generate new problems from each one of the situations that they were given. Then, the line of inquiry developed according to their responses; and aspects of clinical interview (Gingsburg, 1981) were utilized to reveal students' actual thinking. Interviews were audiotaped and the annotated field notes were taken for consideration.

Overall, literature about proportional reasoning (Lesh, Post \& Behr, 1988; Patricia, Post, Behr \& Lesh, 1990) and problem posing (Grundmeier, 2003; Silver \& Cai, 1996; Stickles, 2006) provided a theoretical basis for the data analysis. Content and discourse analysis methods were used to discern meaning embedded in the students' written and spoken expressions (Miles \& Huberman, 1994; Phillips \& Hardy, 2002). Data analysis was an iterative process that evolved gradually. In the first phase of analysis all the problems that had been generated were examined in terms of correctness. Problems that included logical mistake or lack of information were eliminated; they were collected under the category of 'logical mistake and lack of information'. In-depth examination continued on the remaining 
tasks that were mathematically correct and meaningful. Codes were produced from the situations to identify critical features of each one of the problems generated. In the last phase of analysis, a pattern coding was applied and thematically identical and similar codes were collected under the same category. For instance, codes that addressed adaptations made on the underlying logic and the solution methods and strategies of the original problem were gathered under the category of 'structural changes'. Some other categories included, for instance, 'value change', 'story change', 'inserts numerical values', 'simplifying' and 'extension'. Also, problems that had been generated by making changes on more than one aspect of the original task (such as, value change and story change) were classified under the category of 'combination'. Similar approach was followed in the analysis of interview data. Interviews were transcribed and a summary of students' answers to each situation was written up. This document was read thoroughly a couple of times; then codes were established to distinguish sort of reasoning, mathematical notions and instruments that they used in producing new problems. Repeated on different copies of the text this eventually led to the creation of major categories.

\section{Results}

The results indicated that the participants showed better success in generating problems from reformulation tasks; yet, their achievement declined in semi-structured and free problem posing situations. Nevertheless, the majority of the problems that they created could be manipulated by the application of rules, procedures and factual knowledge. The participants' written and spoken answers suggest that their inclination to create routine problems appears to have relations with their past experiences. Most participants lacked an ability to generate cognitively challenging and conceptually rich problems; and in this respect the participants of this study was not proficient enough in problem posing.

While creating problems from reformulation tasks most participants preferred changing story of the original task or the numerical values in it. Some used different techniques such as simplifying or extending the original problem; yet, they did this again by modifying story of the original task or the quantitative values in it. They made no adaptation on the content and the structure of the original situation; rather they stuck to the methods and strategies of the original problem. The results indicated also that the participants' achievements declined when they were confronted with qualitative situations. One of the qualitative reformulation tasks was: If Ahmet ran fewer laps in more time than he did yesterday; would you compare his running speed in these two days? (Derived from Cramer, Post \& Currier, 1993). Nearly three quarter of the participants generated mathematically correct problems (see, Table $A_{1}$ ); yet, only one tenth of these tasks posed cognitive demands and requested new solution methods and strategies.

Semi-structured situations included stimulus, such as a picture or an algebraic expression, to provide problem poser with a general context. In this study five semi-structured situations were used. Two of them included algebraic and arithmetic expressions; two was about real 
life situations (a cake recipe and a car picture travelling on the road), and one was a mathematical model made up rectangular tiles.

Table $\mathbf{A}_{1}$. Results of written exam concerning qualitative reformulation task

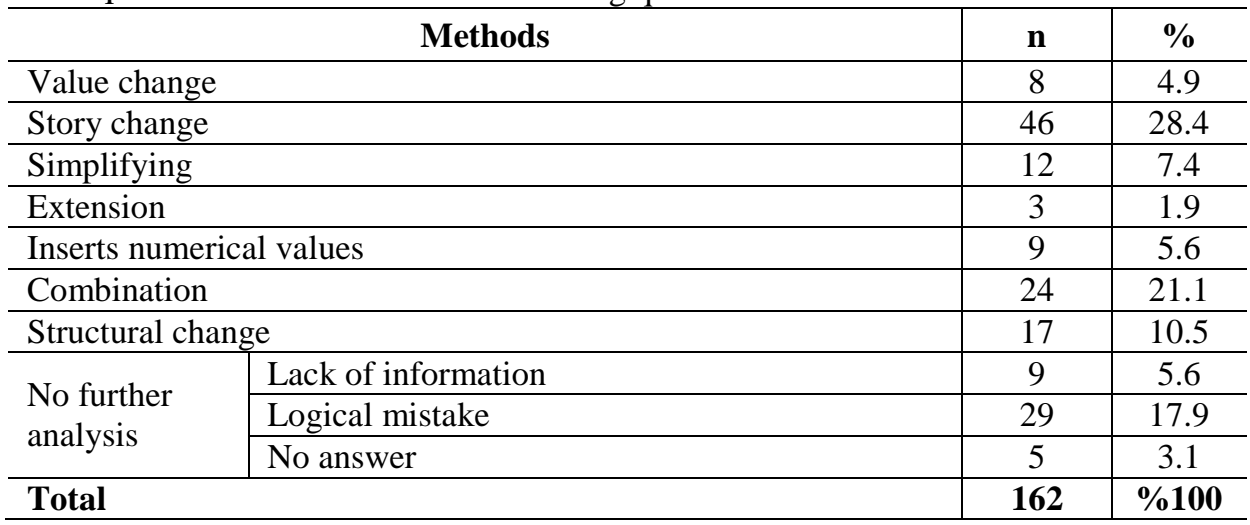

The participants were more successful in generating problems from algebraic expression; and this seems to have relations with their past experiences. They displayed also better success in generating problems from real life situations. However, analysis of the data sets indicated that almost all the problems that they produced were routine tasks that could be manipulated procedurally. For instance, $\% 70$ of the participants generated mathematically correct problem from a cake recipe; yet all the problems included the idea of direct proportion and, thus, could be resolved by the application of related algorithms. Their success declined to $\% 50$ in a situation that included just a car picture traveling on the road, and further to 30 percent in a situation made up rectangular tiles. More than half of the problems that the interviewees generated from this last situation included mathematical mistakes or excluded proportional reasoning. It is interpreted from the participants' written and spoken answers that absence of quantitative values in a situation was the prominent factor negatively affecting their thinking. This was seen more clearly in their attempts to create problems from free problem posing situations. In this respect, the participants were asked to generate a problem that entail proportional reasoning and would be difficult to solve. The results indicated that less than half of the generated problems (\%42) were mathematically correct and included the idea of proportion while $\% 15$ included logical mistake or lack of information. The remaining tasks were also mathematically correct, yet they did not include the idea of proportion; they were about other mathematical notions such as the concept of fraction. Both written exam and interview results indicated that the participants encountered great difficulties in generating high quality problems. In the exam, less than one tenth of the participant was able to generate cognitively demanding tasks that enforce mathematical reasoning and request different methods and strategies to be resolved. 


\section{Discussion and Conclusion}

The importance of problem posing has been recognized by the mathematics education community in Turkey; yet, very few researches have been carried out to examine prospective teachers' proficiencies in this domain. Thus, this study aimed to investigate prospective teachers' proficiencies in generating problems in reformulation, semi-structured and free situations. Our results indicated that the participants' success fluctuates according to characteristics of the situations given. They achieved better in generating problems from reformulation tasks; yet, their success declined gradually in semi-structured and, especially, in free situations. This is reasonable because reformulations tasks involve all the instruments (mathematical ideas, solution methods and strategies, etc.) that the problem posers could capitalize on in generating new problems. Semi-structured and free situations provide nothing other than a general context; thus they request imagination, creativity and high level of reasoning that is difficult for many to incorporate.

The results provide some insight into thinking processes that the participants displayed in generating problems. When posing problems most participants tended to use techniques of changing story of the original problems and the numerical values in it. Inserting numerical values, changing given values or changing result values were all about procedures, not related to the cognitive structure, methods and the solutions strategies. This shows that most of the participants displayed quantitative reasoning, not the qualitative thinking. Most of the tasks that they generated could be resolved by the application of rules and procedures; and in this respect they mirrored characteristics of the simple word problems. Overwhelming majority of the participants displayed lack of proficiency in creating conceptually rich and cognitively challenging tasks. This seems to be resulting from their lack of experiences in this field. Thus, it is suggested that during their undergraduate studies prospective teachers should be engaged in problem posing activities in pure mathematics and mathematics education courses. They would be engaged in semi-structured and free situations in order to enhance their imagination, creativity and critical thinking.

\section{Kaynaklar/References}

Abu-Elwan, R. (1999). The development of mathematical problem posing skills for prospective middle school teachers. In A. Rogerson (Ed.), Proceedings of the International conference on Mathematical Education into the 21st Century: Social challenges, Issues and approaches (Vol. II, pp. 1-8). Cairo, Egypt.

Abu-Elwan, R. (2002). Effectiveness of problem posing strategies on prospective mathematics teachers' problem solving performance. Journal of Science and Mathematics Education in Southeast Asia, 25(1), 56-69.

Behr, M., Harel, G., Post, T., \& Lesh, R. (1992). Rational number, ratio and proportion. In D. Grouws (Ed.), Handbook on research of teaching and learning (pp. 296-333). New York: McMillan. 
Brown, S. I., \& Walter, M. I. (Eds.). (1993). Problem posing in mathematics education. New Jersey: Lawrence Erlbaum Associates.

Çelik, A. (2010). Illköğretim ögrencilerinin orantısal akıl yürütme becerileri ile problem kurma becerileri arasındaki ilişki (Yayınlanmamış yüksek lisans tezi). Hacettepe Üniversitesi, Eğitim Bilimleri Enstitüsü, Ankara.

Christou, C., Mousoulides, N., Pittalis, M., Pitta-Pantazi, D., \& Sriraman, B. (2005). An empirical taxonomy of problem posing processes. ZDM, 37(3), 149-158.

Cramer, K., Post, T., \& Currier, S. (1993). Learning and teaching ratio and proportion: Research implications. In D. Owens (Ed.), Research ideas for the classroom (pp. 159178). New York, NY: Macmillan Publishing Company.

Crespo, S., \& Sinclair, N. (2008). What makes a problem mathematically interesting? Inviting prospective teachers to pose better problems. Journal of Mathematics Teacher Education, 11(5), 395-415.

Dede, Y. ve Yaman, S. (2005). Matematik öğretmen adaylarının matematiksel problem kurma ve problem çözme becerilerinin belirlenmesi. Ĕgitim Araştırmaları Dergisi, 18, 41-56.

English, L. D. (1997). The development of fifth-grade children's problem-posing abilities. Educational Studies in Mathematics, 34, 183-217.

English, L. D. (1998). Children's problem posing within formal and informal contexts. Journal for Research in Mathematics Education, 29(1), 83-106.

Gingsburg, H. P. (1981). The clinical interview in psychological research on mathematical thinking: aims, rationales, techniques. For the Learning of Mathematics, 1(3), 4-11.

Grundmeier, T. A. (2003). The effects of providing mathematical problem posing experiences for $k-8$ pre-service teachers: investigating teachers' beliefs and characteristics of posed problems (Unpublished doctoral dissertation). University of New Hampshire, Durham.

Kilpatrick, J. (1987): Problem formulating: Where do good problems come from? In A. H. Schoenfeld (Ed.), Cognitive science and mathematics education (pp. 123-147). Hillsdale, NJ: Erlbaum.

Korkmaz, E. ve Gür, H. (2006). Öğretmen adaylarının problem kurma becerilerinin belirlenmesi. Ballkesir Üniversitesi Fen Bilimleri Enstitü Dergisi, 8(1), 64-74.

Lamon, S. J. (1995). Ratio and proportion. Elementary didactical phenomenology. In B. P. Schappelle (Ed.), Providing a foundation for teaching mathematics in the middle grades (pp. 167-198). Albany: State University of New York.

Lavy, I., \& Shriki, A. (2007). Problem posing as a means for developing mathematical knowledge of prospective teachers. Proceedings of the 31st Conference of the International Group for the Psychology of Mathematics Education (Vol. 3, pp. 129136). Seoul: PME.

Lesh, R., Post, T., \& Behr, M. (1988). Proportional reasoning. In J. Hiebert \& M. Behr (Eds.), Number concepts and operations in the middle grades (pp. 93-118). Reston, VA: Lawrence Erlbaum.

Leung, S. K., \& Silver, E. A. (1997). The role of task format, mathematics knowledge, and creative thinking on the arithmetic problem posing of prospective elementary school teachers. Mathematics Education Research Journal, 9(1), 5-24. 
Miles, M. B., \& Huberman, A. M. (1994). Qualitative data analysis: An expanded source book (2nd ed.). Thousans Oaks, CA: Sage Publication.

Milli Eğitim Bakanlığı [MEB]. (2013). İlköğretim matematik ögretim programı. Ankara: Milli Eğitim Bakanlığı Yayınları.

Moses, B., Bjork, E., \& Goldenberg, E. P. (1990). Beyond problem solving: Problem posing. In T. J. Cooney, \& C. R. Hirsch (Eds.), Teaching and learning mathematics in the 1990s (pp. 82-91). Reston, VA: National Council of Teachers of Mathematics.

National Council of Teachers of Mathematics [NCTM] (1989). Curriculum and evaluation standards for school mathematics. Reston, VA: National Council of Teachers of Mathematics.

National Council of Teachers of Mathematics [NCTM] (1991). Principals and standards for school mathematics. Reston, VA: National Council of Teachers of Mathematics.

National Council of Teachers of Mathematics [NCTM] (2000). Principles and standard for school mathematics. Reston, VA: National Council of Teachers of Mathematics.

Patricia, H., Post, T., Behr, M., \& Lesh, R. (1990). Qualitative and numerical reasoning about fractions and rates by seventh- and eighth-grade students. Journal for Research in Mathematics Education, 21, 388-402.

Phillips. N., \& Hardy, C. (2002). Discourse analysis: Investigating processes of social construction. United Kingdom, UK: Sage Publication.

Silver, E. A. (1994). On mathematical problem posing. For the Learning of Mathematics, 14(1), 19-28.

Silver, E. A., \& Cai, J. (1996). An analysis of arithmetic problem posing by middle school students. Journal for Research in Mathematics Education, 27, 521-539.

Stickles, P. R. (2006). An analysis of secondary and middle school teachers' mathematical problem posing (Unpublished doctoral dissertation). Indiana University, School of Education, Indiana.

Trends in International Mathematics and Science Study [TIMSS]. (2011). Mathematics framework: Chapter-1. Retrieved November 15, 2016 from http://timss.bc.edu/timss2011/downloads/TIMSS2011_Frameworks-Chapter1.pdf

Van de Walle, J. A., Karp, K. S., \& Bay-Williams, J. M. (2012). Elementary and middle school mathematics: teaching developmentally (S. Durmuş, Çev. Ed.). Boston: Pearson.

Yıldırım, A. ve Şimşek, H. (2008). Sosyal bilimlerde nitel araştırma yöntemleri. Ankara: Seçkin Yayıncılık.

Yin, R. K. (2003). Case study research: design and methods (3rd ed.). Thousand Oaks, CA: Sage.

\section{Kaynak Gösterme}

Bayazit, İ. ve Kırnap-Dönmez, S. M. (2017). Öğretmen adaylarının problem kurma becerilerinin orantısal akıl yürütme gerektiren durumlar bağlamında incelenmesi. Türk Bilgisayar ve Matematik Eğitimi Dergisi, 8(1), 130160.

\section{Citation Information}

Bayazit, İ. \& Kırnap-Dönmez, S. M. (2017). Prospective teachers' proficiencies at problem posing in the context of proportional reasoning. Turkish Journal of Computer and Mathematics Education, 8(1), 130-160. 